\title{
Organizing Violence
}

\section{Citation}

Bates, Robert, Avner Greif, and Smita Singh. 2002. Organizing violence. Journal of Conflict Resolution 46, no. 5: 599-628.

\section{Published Version}

http://dx.doi.org/10.1177/002200202236166

\section{Permanent link}

http://nrs.harvard.edu/urn-3:HUL.InstRepos:3707095

\section{Terms of Use}

This article was downloaded from Harvard University's DASH repository, and is made available under the terms and conditions applicable to Other Posted Material, as set forth at http:// nrs.harvard.edu/urn-3:HUL.InstRepos:dash.current.terms-of-use\#LAA

\section{Share Your Story}

The Harvard community has made this article openly available.

Please share how this access benefits you. Submit a story.

\section{Accessibility}




\title{
Organizing Violence
}

\author{
Robert Bates, Avner Greif, and Smita Singh
}

CID Working Paper No. 71

September 2001

(C) Copyright 2001 Robert H. Bates, Avner Greif and Smita Singh and the President and Fellows of Harvard College

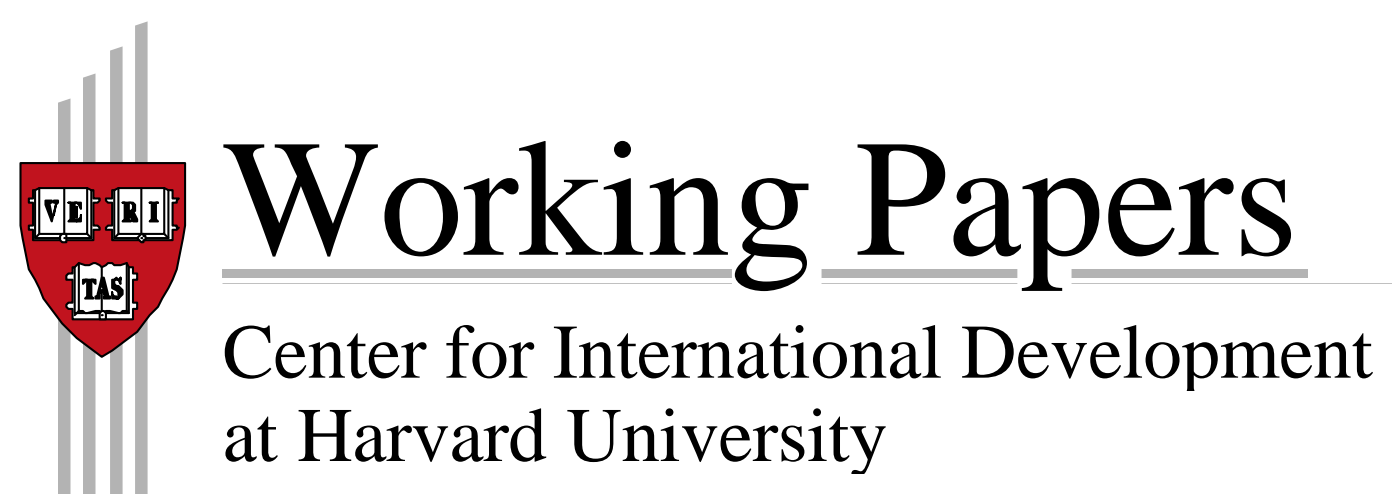




\title{
Organizing Violence $=$
}

\author{
Robert Bates, Avner Greif, and Smita Singh
}

\begin{abstract}
Coercion is as normal a part of life as is exchange; what matters is not its presence or magnitude but rather its structure and form. Violence can take the form of predation; it then results in mere redistribution. But violence can be rendered socially productive; it can be employed to defend property rights, thereby strengthening the incentives to engage in productive activity. To explore how violence can be rendered a source of increased welfare, we develop a model of a stateless society and then introduce a specialist in violence. Using the model and case materials, we explore the conditions under which the specialist will utilize her coercive capabilities not to engage in predation but rather to strengthen the incentives to engage in productive effort.
\end{abstract}

keywords: violence; political order; game theory; coercion; political economy

JEL codes: C71; D74; N40; O10

Prof. Robert H. Bates is Eaton Professor of the Science of Government in the Government Department at Harvard University and Faculty Fellow at the Center for International Development at Harvard University.

Prof. Avner Greif is the Bowman Family Endowed Professor in Humanities and Sciences at the Department of Economics at Stanford University.

Smita Singh is a Fellow at the Harvard Academy for International and Area Studies.

$=$ This work was supported by the research division of the World Bank, the United States Institute of Peace (Grant No. USIP-02597S), and the National Science Foundation (Grant No.SES-09905568). The authors wish to acknowledge comments and criticisms received from audiences at the World Bank sponsored workshop at Princeton University on "The Economics of Political Violence", March, 2000; the Research Workshop in Positive Political Economy at Harvard University, April 2000; the Annual Meetings of the American Political Science Association, August 2000;Instituto Tecnologico Autonomo de Mexico; and Centro de Investigacion y Docencia Economicas (CIDE). Special thanks go to Federico Estevez (ITAM), Gabriel Negretto (CIDE) 


\section{Introduction}

The premise of this paper is that coercion is as normal a part of life as is exchange; what matters is not its presence or magnitude but rather its structure and form. ${ }^{1}$ In stateless societies, coercion is privately provided; violence is employed to engage in, and to defend against, predation. At best it results in mere redistribution; being destructive, it more often results in a loss of social welfare. When organized, however, violence, can be socially productive; it can be employed to defend property rights, thereby strengthening the incentives to engage in productive activity.

To explore how violence can be organized and rendered a source of welfare, we develop a model of a stateless society, in which people's rights to the product of their labor are secure only if they possess coercive capabilities. We then incorporate into the model a specialist in violence and pose the following questions: Under what conditions will such a specialist utilize her coercive power only against those who have inflicted violence upon others? Under what conditions can the specialist in violence enhance the welfare of the economic agents by providing protection for property rights? When, in other words, can specialists in violence render coercion socially productive?

By addressing these questions, we probe the nature of the state. It is important to stress that in doing so we do not explore the origins of the state; we do not advance a model of equilibrium selection. Rather, we seek to characterize equilibria and thus explore the properties of political arrangements.

Most scholars follow Weber (1958) and view the state as a source of political order, based upon its monopoly over the means of violence. Within this framework, some treat the state as an instrument for enhancing the social welfare (see the review in Grindle 1991) while others view it as an instrument of involuntary redistribution (Findlay 1991). Some treat it as developmental (e.g. Evans 1995) and others as predatory (e.g. Lal 1984). ${ }^{2}$ We, however, depart from the Weberian perspective. Order, we argue, is problematic. Citizens can and do revolt, employing their control over private means of

\footnotetext{
${ }^{1}$ Hirshleifer (1994) and Garfinkel and Skaperdas (2000) elaborate on the need to integrate the analysis of the "dark side" in economics.
} 
violence to overturn the state. We also note that states that have been founded consensually may, ex post, become predatory; and that a predatory band may form a state that, ex post, enhances the collective welfare. The existence and properties of a state thus can not be assumed. In search of an approach that treats both as endogenous, we instead turn to rational choice analysis. ${ }^{3}$

When deploying this mode of reasoning, we depart from those who utilize static, general equilibrium models that highlight the role of technology and in particular the technology of violence. We instead adopt a dynamic framework. And while previous analyses have restricted the choice of actions to production or defense, we allow citizens to engage in both production and military activity. We also endow them with a third alternative: that of leisure. Employing game theory, we uncover a fundamental tradeoff in the political economy of stateless societies. In such societies, we find, poverty can be the price of peace. The inverse also holds: violence can be the price of prosperity. An attraction of the state, we argue, is that it offers a means of transcending this tradeoff, therefore (as we prove) making possible the attainment of higher levels of welfare.

When exploring the properties of societies with states, we investigate the equilibrium conditions of a "contract" between a specialist in violence and private agents. We demonstrate that there is a price at which specialists in violence will deploy coercion productively and protect property rights, eliciting the movement of resources from unproductive leisure and predation to productive labor. This reorganization of coercion, we argue, transforms violence into governance and, under conditions that we specify below, renders coercion welfare enhancing.

The paper divides into four parts. The first is devoted to stateless societies; the second, to societies with states; the third, to the breakdown of political order and the

\footnotetext{
${ }^{2}$ And some as both (e.g. North 1981,Olson 1993, Levi 1988).

${ }^{3}$ See, for example, the sequence of works by Skaperdas (Skaperdas 1992; Skaperdas and Syropoulos 1996; Skarpedas and Syropoulos 1995), Konrad and Skaperdas (Konrad and Skaperdas 1996), Skaperdas and Syropoulos (Skarpedas and Syropoulos 1995), Grossman (Grossman 1997; Grossman 1991; Grossman and Kim 1995). Moselle and Polak (Moselle and Polak 1999b) and Muthoo (Muthoo 2000) utilize evolutionary and classical game theory respectively. The latter's model is the closest to ours as further discussed after we introduce the model. Greif (1998) advances a model and historical analysis of a situation in which a state is established when armed clans hire a specialist in violence to contain their own military ability.
} 
transition to warlordism; and the last to a discussion of the normative implications of the analysis. Within each part, theory engages case materials. Drawing our theory from the theory of games and our cases from both history and the modern world, we explore:

- The properties, and limitations, of stateless societies.

- The conditions under which political order can exist.

- The conditions under which states collapse.

- And the conditions under which states advance the welfare of their citizens by rendering coercion economically productive.

\section{Part I: Stateless Societies}

Informing the logic of our model are the political experiences of stateless societies. Consider the following two examples. Separated by centuries, both nonetheless illustrate the interplay between prosperity and violence.

\section{An Example from the $13^{\text {th }}$ Century}

In the late $13^{\text {th }}$ Century, towns such as Paris, London, Rouen, Bruges, and Ghent joined the ranks of the Mediterranean city-states as important centers of commerce. While Northern Europe may have experienced prosperity in the $13^{\text {th }}$ Century, it did not experience peace. What Wallace MacCaffrey would write of the $15^{\text {th }}$ Century was true of the $13^{\text {th }}$ as well: in "the absence of a strong royal personality," the political world then turned into "an arena where no prizes ... were out of reach, but where there was no security for the life, liberty, or property of the contestants" (MacCaffrey 1961, 96).

The prosperity of the $13^{\text {th }}$ Century was marked by the rise of the textile industry. In northern Europe, investors began draining deltas and swamplands, diverting rivers, and employing waterpower to drive machines that ground grain, shaped metal, and carded wool. The urban centers of the lowlands, and in particular Bruges, became major centers for the production of textiles. And with an increase in the demand for woolens came a rise in the demand for sheep. While cities in the lowlands produced textiles, it was the 
rural counties of England that provided the wool. Consulting treatises on estate management, abbots and magnates throughout England turned to the raising of sheep. In the words of Eileen Power, the $13^{\text {th }}$ Century became "the golden age of English demesne farming" (Power 1941, 35).

With the rise in the demand for wool, land rights became more valuable. In seeking to vest their rights in property, rural magnates invested in military power. Tracing the career of William Marshall, perhaps the most famous magnate in the Angevin era, Crouch $(1990,4)$ notes that Marshall, like others, "attach[ed] independent, influential men into his following." Extracting money from those who held land by right of feudal service, Marshall built a military household that he endowed with his own device and colors. As did Marshall, so did others convert wealth into political followings. Rural elites formed liveried companies that then provided the muscle with which both to expand their claims to land and to defend their property. Rural England may have become wealthy, then. But it also became violent, entering the period which McFarlane (1973; 1981) and others (e.g. Hicks 1995) have called the era of "Bastard Feudalism".

\section{An Example from the $20^{\text {th }}$ Century}

The covariation of wealth and violence reflected in $13^{\text {th }}$ century England also characterizes societies in the contemporary developing world as well. Consider, for example, the case of Kenya and the origins of the post-war rebellion known as Mau Mau.

Many of the books written about Mau Mau -- and there are scores of them (Clough and Jackson 1975) -- emphasize its ideology. For liberals, it sought to overturn colonial rule and the domination of whites over blacks in Kenya (Rosberg and Nottingham 1966). For Marxists, it sought to impede the further incursion of global capitalism into the developing areas (Barnett and Njama 1966). Increasingly, however, scholars have turned from such macro-level interpretations to micro-level studies of the communities that provided its political base (e.g. Cowen 1978).

The rural wing of the Mau Mau rebellion originated among the Kikuyu communities of Central Kenya. The Kikuyu constitute one of the many stateless societies 
of East Africa (Lambert 1956; Middleton 1953). Rather than kings or chiefs, the Kikuyu were governed by families and land-owning associations, who placed representatives on councils that regulated the affairs of the tribe (see also Kenyatta 1953).

In the $20^{\text {th }}$ Century, two forces transformed the economic and political lives of the Kikuyu. The first was the arrival of the white settlers, who seized lands that they deemed idle or vacant; many of these lands were in fact owned but not occupied, as the Kikuyu had temporarily vacated them in the midst of a recent drought and famine (Leakey 1977). Second came a radical expansion of economic opportunities. The low-lying lands of the Kikuyu spread into the suburbs of Nairobi, which was the most rapidly growing city in East Africa. And those that lay at higher elevations proved ideally suited for the production of coffee, one of the most valuable products traded in world markets. Just as the lands of the Kikuyu became scarce, then, they also became more valuable.

In response to the increased value of real property, people began to "raid" the holdings of others. Initially, they employed litigation, contesting the land rights of others in order to expand their own. Aware of the possibility of being subject to suits, families invested in legal defenses and filed counter suits to those who employed the courts to harass them (Cowen 1978; Kershaw 1997; Njonjo 1997). As Kershaw (1997) states in her study of Igi, a Kikuyu community in Kiambi: "If Njoroge brought a case over a small part of Mungai's land, nothing prevented Mungai, perhaps to warn Njoroge against further litigation, from responding by bringing a case over a part of Njoroge's land" (Kershaw 1997, 106).

As politicians from the center penetrated the Kikuyu countryside, they played upon the tensions within Kikuyu communities. They transformed land cases into political causes to recruit supporters. And as the nationalist movement adopted more militant tactics, litigation gave rise to violence. In the village studied by Kershaw, a group of politically active youths murdered a group of rivals. Seeking to defend himself in court, one of the accused brought to the surface the tensions that underlay the case. He "lies," the accused stated of a witness, "because if I am hanged, he will inherit my land" (Kershaw 1997, 254). 
The case of Mau Mau thus evidences relationships that parallel those in England. An increase in the value of land coincided with the channeling of resources into coercive action: litigation, initially ${ }^{5}$, but later deadly violence. ${ }^{6}$ Both the rise of conflict in $13^{\text {th }}$ Century England and $20^{\text {th }}$ Century Kenya suggest that when private parties provide their own defenses, wealth and violence go hand-in-hand. Why? To address this question, we incorporate the salient features of such societies into a formal model that we can manipulate and explore.

\section{A Model of Protection and Production in Stateless Societies}

In stateless societies, the relevant decision-makers are often groups, such as lineages and communities. These groups can allocate their resources between economic activities, military activities and leisure; they are not farmers or warriors at any given time, but rather possess the capabilities of both. Conflict appears to be an on-going, an almost permanent feature of many such communities; disputes and potential skirmishes lie under the surface, ready to emerge. These attributes shape the specification of our model.

For simplicity, we introduce but two symmetric players, thus enabling us to abstract from the complications that would arise from the formation of coalitions. ${ }^{7}$ These players can be individuals or tribes, clans or even ethnic groups. A generic player is referred to as player $i$, where $i=1,2$. Each player has a given amount of resources of

\footnotetext{
${ }^{5}$ Indeed, Kershaw notes, given the costs of filing cases, recording cases, pursuing appeals, locating and reimbursing witnesses, and spending time away from work attending court, "litigation costs" came to exceed "all other costs of production" (Kershaw 1997, 106).

${ }^{6}$ Some have stressed the immiseration of peasant agriculture in Kenya (e.g. Barnett and Njama 1966); and yet empirical investigations highlight the growing earnings of the peasantry in Central Province, including and especially the Kikuyu (e.g. Cowen 1978, Kitching 1980). Nor was Mau Mau a protest against capitalism. Among its leaders numbered several of the most successful Kikuyu businessmen (Cowen 1978; Njonjo 1997). And at the grass roots level, violence grew from a struggle for rights of ownership that would enable Kikuyu farmers to increase their incomes from commercial agriculture. Mau Mau did, of course, fight for the return of lands seized by white immigrants (Rosberg and Nottingham 1966); but it also fought over land rights within the Kikuyu community. Of the many deaths attributed to Mau Mau, only 32 white colonists died at the hands of Mau Mau, but over 2,000 Kikuyu were killed (Edgerton 1989, 106).

${ }^{7}$ To ease exposition, we ignore all issues relating to the internal organization of the actors, including collective action problems, decision-making processes, and free riding. We simplify by assuming two players. So long as the players could not cooperate in the use of violence, adding more players would not weaken our results. Indeed, having more players would make the first best less likely and the noncooperative equilibrium more likely, thus strengthening our argument. An account of the rise of the Mau Mau, based on linking prosperity with violence, appears to accord with the facts at least as well as do interpretations offered by others.
} 
time and effort, denoted by $\mathrm{T}_{i}$, that she must decide how to allocate each period between work, military ability, and leisure.

Only the resources devoted to working, $w_{i}$, are socially productive, and result in an output of $\mathrm{F}\left(w_{i}\right)$ for player $i .^{8} \quad$ Player $i$ can also devote her resources to obtaining military skills, $m_{i}$, which she can use either to raid the other player's wealth or to defend her own property. The investment in military skills yields payoffs determined by the function $\mathrm{M}(\bullet)$ : If player $i$ attacks and player $-i$ defends, then $\mathrm{M}\left(m_{i}, m_{-i}\right)$ is the share of player $-i$ 's wealth that player $i$ is able to expropriate if she allocates $m_{i}$ units of effort to perfecting her military capabilities, and the other player, player $-i$, allocates $m_{-i}$ units. ${ }^{9}$ The more one invests in military capability relative to the other, the higher one's return from raiding; by the same token, the more one is able to engage in defense, the more difficult it is to expropriate her wealth. $\mathrm{M}(\bullet)$ thus captures the correspondence between military capabilities, both offensive and defensive, and redistributive outcomes.

Each period is divided into two sub-periods. At the start of the first sub-period, players simultaneously allocate their finite resources among working $\left(w_{\mathrm{i}}\right)$, acquiring military capabilities $\left(m_{i}\right)$, and leisure $\left(l_{i}\right)$, where $w_{i}, m_{i}, l_{i} \quad 0$, and $\mathrm{T}_{i}=w_{i}+m_{i}+l_{i}$. In the second sub period, after observing the allocation of the other player, each player must also decide whether to utilize her military skills, and raid the wealth of the other. Define $r_{i}=\{0,1\}$ to equal 1 if player $i$ raids and equal 0 if she does not attack. The net income of player $i, \mathrm{I}_{i}\left(w_{i}, m_{i}, w_{-i}, m_{-i}, r_{i}, r_{-i}\right)$ then equals her income from work and raiding, if any party raided, less her losses from being raided: $\mathrm{I}_{i}(\bullet)=\mathrm{F}\left(w_{i}\right)+r_{i} \mathrm{~F}\left(w_{-i}\right) \mathrm{M}\left(m_{i}, m_{-i}\right)-r$. ${ }_{i} \mathrm{~F}\left(w_{i}\right) \mathrm{M}\left(m_{-i}, m_{i}\right)$.

Any resources not devoted to $w_{i}$ or $m_{i}$ increase the amount of leisure, $l_{i}$, that a

\footnotetext{
${ }^{8} \mathrm{~F}(\bullet)$ is assumed to be a twice continuously differentiable, concave function that maps from player $i$ 's effort to her income.

${ }^{9}$ The following is assumed with respect to the function $\mathrm{M}$ : (i) $\mathrm{M} \in[0,1]$. Obviously, no player can expropriate more than what the other possesses. (ii) $\mathrm{M} / m_{i} \quad 0$ and $\mathrm{M} / m_{-i} \quad 0 ;{ }^{2} \mathrm{M} / m_{i}{ }^{2} \quad 0$ and ${ }^{2} \mathrm{M} / m_{-\mathrm{i}}{ }^{2} \quad 0 . \mathrm{M}$ is non-decreasing in $m_{i}$ and non-increasing in $m_{-i}$. It is a twice continuously differentiable function with decreasing returns, which means that the portion of player $-i$ 's wealth that player $i$ can expropriate is concave in $\mathrm{m}_{\mathrm{i}}$ and convex in $\mathrm{m}_{-\mathrm{i}}$. (iii) $\mathrm{M}>0$ iff $m_{i}>0$. That is, if and only if player $i$ invests in military ability can she expropriate part of the other player's income. (iv) ${ }^{2} \mathrm{M} / m_{i} m_{-i}<0$. The cross partial derivative of $\mathrm{M}$ with respect to $m_{i}$ and $m_{-i}$ is negative. That is, the more military ability a person
} 
player consumes. Player $i$ 's utility from income and leisure is denoted by $\mathrm{U}\left(\mathrm{I}_{i}(\bullet), l_{i}\right)$, where $\mathrm{I}_{i}$ is that player's income and $l_{i}$ are the resources allocated to leisure. We maintain the usual assumptions with respect to the function $\mathrm{U}(\bullet)$, including concavity in each of its elements.

In sum: Player $i$ 's action set in the first sub period is $\mathrm{A}_{i}=\left\{\left(w_{i}, m_{i}, l_{i}\right): w_{i}, m_{i}, l_{i} \geq 0\right.$ and $\left.w_{i}+m_{i}+l_{i}=\mathrm{T}_{I}\right\}$ while her action set in the second sub period is $r_{i}:\left\{w_{i}, m_{i}, l_{i,} w_{-i}, m_{-i}\right.$, $\left.l_{-i}\right\} \rightarrow\{0,1\}$ and her one-period payoff is $ð_{i}\left(w_{i}, m_{i}, l_{i}, w_{-i}, m_{-i}, r_{i}, r_{-i}\right)=\mathrm{U}\left(\mathrm{I}_{i}(\bullet), l_{i}\right)$.

\section{Analysis}

Employing this framework to explore behavior in societies without states, we first explore equilibria in a single shot game. Doing so enables us to highlight the requirements for sustaining the first best as an equilibrium and underscores the likelihood that actors will instead devote resources to unproductive military use. This framework also enables is to explore the more likely outcome, which we label the all-defect equilibrium, in which agents invest in military capabilities as a way of deterring raids by others. And the all-defect equilibrium provides us with the payoffs which become the reversion point for the second step of the analysis: an examination of the game in repeated play. ${ }^{10}$ Through these analyses we learn that:

acquires, the more she is able to engage in defense and the more difficult it is to expropriate her wealth. For a general analysis of such contest functions see Skarpedas (1996).

${ }^{10}$ When employing a repeated game framework, we ignore the possibility that one agent can, using his military ability, eradicate the other. We maintain this assumption because we want to consider stateless societies in which there are on-going interactions between groups -- be they tribes, communities, lineages, or villages. Alternatively, one can consider our analysis as related to a situation in which property rights are determined endogenously through interactions among the economic agents. The degree to which one can secure property rights depends upon relative coercive capabilities. See, for example, Skaperdas 1992, Grossman and Kim 1995, and Muthoo 2000.

Although the model's formulation is inspired by the historical experience of stateless societies, at the same time it ignores, for simplicity sake, potentially important aspects of conflict situations of the sort we seek to explore. It puts to the side, for example, evolutionary forces and specialization in the use of violence (as in Moselle and Polak 1999a), asymmetries among the agents (as in, for example, Grossman and Kim 1995 and Muthoo 2000); the impact of past conflicts on one's current military capabilities (discussed in Fearon 1996); uncertainty and loss of potential exchange (discussed in Skarpedas 1996), and moral hazard issues (explored in Addison 2000). By the same token, this framework enables us to extend the analysis beyond that possible in other works. Specifically, it allows us to examine the endogenous determination of prosperity and violence. See the papers citied above as well as Usher 1989 and Skaperdas 1992. The model in Muthoo 2000 is closest to ours. While it explores the impact of asymmetries (which 
- In societies in which coercion is privately deployed for the raiding and protection of property, it is difficult to sustain the first best investment in production. Indeed, the higher is the society's potential economic prosperity, the less likely is the first best to be sustainable as an equilibrium outcome.

- In such societies, violence is often the price paid for prosperity: An equilibrium with positive investments in military capabilities can Pareto dominate the optimal equilibrium with none.

- And by implication: to escape from the trade-off between peace and prosperity, such societies might seek the introduction of a centralized form of political order. They might seek thereby to shed the constraints on their welfare imposed by this trade-off.

\section{A Single-shot Framework}

First best equilibrium. We begin by examining a symmetric Nash equilibrium of the one shot version of the game, which we call the first best equilibrium. A necessary condition for the first best allocation of resources to hold in equilibrium in a single shot game is that:

$$
\frac{\partial F\left(w_{i}^{F B}\right)}{\partial w_{i}} \geq F\left(w_{-i}^{F B}\right) \frac{\partial M\left(m_{i}=0, m_{-i}=0\right)}{\partial m_{i}}
$$

That is, for an allocation to be an equilibrium (denoted by the superscript FB) in the oneshot game, the marginal productivity of military effort must be less than the marginal productivity of work for both players.

The RHS of equation (1) is the marginal productivity of military effort; the LHS is the marginal productivity of labor. The marginal productivity of resources devoted to military preparedness and plundering must be less than the marginal productivity of resources devoted to productive labor. Since acquiring military ability and raiding yield no income for either player, the first best allocation of resources is based upon an optimal 
allocation of resources to working and leisure, with no military investment. Even when one player is vulnerable to a raid (i.e., $m_{-i}=0$ ), the other nonetheless must find it in her interests to refrain from what promises to be a successful raid if she acquires military ability (i.e., $\left.m_{i}>0\right)$.

A moment's reflection illustrates the implausibility of this requirement. The equilibrium requires that people must refrain from theft in the presence of such temptations as unprotected crops and unguarded cattle. Such examples underscore the difficulty of achieving the first best outcome in a single period game. For the broader argument of the paper, it is also important to note that in a single play of the game the requirements for the first best equilibrium are less likely to hold the higher the total product, $\mathrm{F}\left(w_{-i}^{\mathrm{FB}}\right)$ and the lower the marginal productivity of working, $\mathrm{F}\left(w_{i}^{\mathrm{FB}}\right) / w_{i}$. Insofar as economic prosperity implies greater total production and decreasing marginal returns to labor, the implication is clear: the higher the level of economic prosperity, the more difficult it is to resist the temptation to engage in predation.

In a single play of the game the first best allocation is thus not likely to be sustainable as an equilibrium outcome. Rather, we should expect a second equilibrium to prevail, which we call the all-defect equilibrium, in which private agents divert resources from production to the acquisition of military capabilities.

All-defect equilibrium. In this equilibrium (denoted by the superscript D), each player, given the actions of the other player, will invest in military capabilities and productive labor to the point where the marginal benefit from working equals the marginal benefit from increased military capabilities, both offensively and defensively. Using the first order conditions, we can characterize this equilibrium by the following relations for $\mathrm{i}=1,2:^{11}$

$$
\frac{\partial F\left(w_{i}^{D}\right)}{\partial w_{i}}-\frac{\partial F\left(w_{i}^{D}\right)}{\partial w_{i}} M\left(m_{-i}^{D}, m_{i}^{D}\right)=F\left(w_{-i}^{D}\right) \frac{\partial M\left(m_{i}^{D}, m_{-i}^{D}\right)}{\partial m_{i}}-F\left(w_{i}^{D}\right) \frac{\partial M\left(m_{-i}^{D}, m_{i}^{D}\right)}{\partial m_{i}}
$$

\footnotetext{
${ }^{11}$ See Appendix, Part I, Sub-game Perfect Nash Equilibria in a Single Shot Game: All-Defect Equilibrium, $(A-4)-(A-5)$.
} 
The left hand side of the equation represents the marginal increase in income due to a player's labor effort (or rather the part of it that she does not lose to raids). The terms on the right record the marginal increase in income due to the acquisition of military capability, both for raiding and defense. In equilibrium, if one player were to devote less effort to violence than $\mathrm{m}^{\mathrm{D}}$, the other would find it desirable to raid, since the marginal benefit of raiding would then be higher than the marginal benefit of work. Under such circumstances, a player who does not prepare for violence would loose more to the other player than she would gain from shifting her effort from military preparedness to productive labor.

In this equilibrium, people devote effort to military preparedness, even though it is costly and unproductive to do so. In equilibrium, each player's net income from predation is zero, given the symmetry of the game; since both raid and defend with $\mathrm{m}^{\mathrm{D}}$ devoted to military effort, neither gains from this expenditure. The equilibrium thus yields positive amounts of resources devoted to violence, and a loss of social welfare. ${ }^{12}$

\section{Repeated Play}

To deepen our understanding of prosperity and violence in stateless societies, we need to extend our analysis to include the possibility of repeated play. A characteristic of stateless societies, after all, is that being based on kinship, they are built upon long-term relationships. In addition, contemporary scholars (Keohane 1984; Bates 1983; Taylor 1987) often invoke the so-called Folk Theorem (Fudenberg and Maskin 1986) to account for political order. For both reasons, we explore patterns of interaction within a multiperiod framework.

As is well known, in repeated play, if the private agents' discount factor, $\delta_{\mathrm{i}}$, is sufficiently close to one, the first best outcome can be attained in equilibrium. The shadow of the future (Axelrod 1984) provides incentives for people to cooperate, and so

\footnotetext{
12 Note that because we assume that there is no fixed cost of raiding beyond the investment in $\mathrm{mD}$, the players may or may not actually raid in equilibrium.
} 
achieve the first best as an equilibrium outcome. ${ }^{13}$ Less well recognized is that, as in the case of a single round of play, the conditions necessary for the attainment of the first best in repeated play settings are restrictive and demanding. Both players must be sufficiently patient. Indeed, each must be so patient that, even were one to lack means of defense, the other would not raid, out of a fear of a future reversion to the all defect equilibrium. And their discount rates and expectations of the discount rate of the other must be common knowledge.

Imbedding the formal analysis in actual settings highlights additional considerations that reduce the likelihood of achieving the first best as an equilibrium. Just as the Folk Theorem implies that for a given set of payoffs, there exists a discount rate that will support cooperation as an equilibrium strategy, so too does it imply that for a given discount rate, there exists a potential gain from defection that will undermine cooperation as an equilibrium choice of strategies. Even were a cooperative equilibrium to prevail that would support the first best level of welfare, it would likely be transitory. Should technology change and prosperity grow, people would find defection an increasingly attractive alternative. For a given discount factor, there is therefore a limit to the level of prosperity that can be supported as an equilibrium outcome without investment in defensive capabilities. ${ }^{14}$

For these reasons, we join with North (e.g. 1990, 12-16) in doubting the possibility of securing through repeated play the first best as an equilibrium outcome. We therefore turn to the analysis of two alternative equilibira. The first we call the nomilitary investment equilibrium; the second, the positive military investment equilibrium. In exploring their properties, we employ the all defect equilibrium to specify the payoffs to players should they stray from the equilibrium path. Our inquiry highlights that, in general, in societies without states, the price of peace can be prosperity; the most efficient no-military equilibrium sustainable as an equilibrium in a repeated setting implies that

\footnotetext{
${ }^{13}$ See Appendix, Part I, First Best Equilibrium in a Repeated Play Game, (A-1)-(A-5).

${ }^{14}$ See Appendix, Part I, Sub-game Perfect Nash Equilibria in a Single Shot Game: All-Defect Equilibrium, (A-5). As expression (A-5) suggests, to maintain the first best as a SPNE in the face of increased rewards to defection, the players must become more patient; the time discount factor must rise. See (A-5) in the Appendix.
} 
peace is sustained by consuming a very large amount of leisure. We thus also find that the price of prosperity may be investment in the means of violence; the most efficient private military equilibrium implies that by acquiring military capabilities, private agents in self-help societies may render it rational to shift more resources from leisure to productive activities.

No-military investment equilibrium. The strategy profile for the no-military investment equilibrium (NM) calls for player i to devote $\mathrm{w}_{\mathrm{i}}^{\mathrm{NM}}$ units of resources to productive work and $\mathrm{T}-\mathrm{w}_{\mathrm{i}}{ }^{\mathrm{NM}}$ units to leisure with no resources allocated to $\mathrm{m}_{\mathrm{i}}$ as long as the other player has never raided or produced more than $\mathrm{w}_{-i}{ }^{\mathrm{NM}}$ and to revert to the alldefect (D) equilibrium strategy otherwise. ${ }^{15}$

Consider the situation in which the one-time payoffs to defection are sufficiently high and the discount factor sufficiently low so that future punishments fail to deter aggression. ${ }^{16}$ In such a case, what are the properties of the no-military investment equilibrium that provides the players with the highest payoff? Clearly, this equilibrium requires that a player's strategy profiles include retaliation for raids by reverting to the all-defect equilibrium strategies. If the shadow of the future is not enough to deter raiding, then for peace to prevail without investment in military ability, the players' strategy profiles must be such that the gains from raiding are reduced. This can be done only by specifying a level of work effort, $\mathrm{w}_{\mathrm{i}}{ }^{\mathrm{NM}}$, low enough to forestall raiding. In the most efficient NM equilibrium, each player deters the other from raiding by threatening to revert to the all-defect equilibrium and by making herself poor enough so that raiding is not profitable. 17

Now suppose there was some incremental increase in military investment -though less than the levels in the all-defect equilibrium -- that might allow a player to shift resources from leisure to productive work. Might such an equilibrium yield higher levels of welfare? In other words, if poverty is the price of peace, could investment in the

\footnotetext{
15 Note that the most efficient equilibrium in the repeated game, the first best allocation, is a special case of the no-military investment equilibrium. It is the one in which $\mathrm{w}_{\mathrm{i}}^{\mathrm{NM}}=\mathrm{w}_{\mathrm{i}}^{\mathrm{FB}}$ and $\mathrm{l}_{\mathrm{i}}^{\mathrm{NM}}=\mathrm{l}_{\mathrm{i}}^{\mathrm{FB}}$.

${ }^{16}$ But less than the amount that characterizes the all-defect equilibrium, $0<\mathrm{m}_{\mathrm{i}}{ }^{\mathrm{PM}}<\mathrm{m}_{\mathrm{i}}{ }^{\mathrm{D}}$. In the circumstances posited in the text, the conditions for the first best equilibrium are not satisfied.

${ }^{17}$ See Appendix, Part I, No Military Investment Equilibrium, (A-6)-(A-8).
} 
capacity to fight lead to greater prosperity? To evaluate this possibility, we turn to the second equilibrium.

Positive -military investment equilibrium. A positive-military investment equilibrium (PM) resembles the no-military investment equilibrium, except that each agent devotes positive amounts of effort to the acquisition of military capability. ${ }^{18}$ The amount devoted to work is also greater, $w_{i}{ }^{\mathrm{PM}}>w_{i}^{\mathrm{D}}$. Each player's strategy calls for investing $m_{i}{ }^{\mathrm{PM}}$ units of effort to military ability and $w_{i}{ }^{\mathrm{PM}}$ units to work, and refraining from raiding, as long as the other player has never raided and has also allocated $w_{-i}{ }^{\mathrm{PM}}$ to work and $m_{-i}{ }^{\mathrm{PM}}$ to military preparedness. The equilibrium strategy also calls for raiding and then reverting to playing the all-defect strategy forever if the other player has ever allocated units $m_{-i} \quad m_{-i}{ }^{\mathrm{PM}}$ to military ability or more than $w_{-i}{ }^{\mathrm{PM}}$ units to productive labor.

A significant feature of the positive-military investment equilibrium is that despite the wasteful investment in military resources, the outcome can Pareto dominate the most efficient no-military investment equilibrium. In the NM equilibrium, the amount of effort devoted to work is constrained by the need to reduce the productivity of the other player's raids; residual resources are devoted to leisure rather than to labor. Because they devote more resources to deterring raiding, those who adopt a PM equilibrium strategy can devote more resources to productive activity as well. The PM equilibrium therefore dominates the NM equilibrium when a redistribution of effort in the NM equilibrium from leisure to work and military preparedness yields an increase in economic output that compensates for the loss of leisure, while still being low enough to ensure that raiding (which entails a reversion to the all-defect equilibrium) remains unprofitable. ${ }^{19}$

In a PM equilibrium, society is characterized by constant displays of military ability or skirmishes. The demonstration of force by one player indicates to the other that should she think of raiding, the profitability of such raids would be minimal. Such societies are warlike, but they also are economically more productive than societies whose citizens do not bear arms.

\footnotetext{
${ }^{18}$ But less than the amount that characterizes the all-defect equilibrium, $0<\mathrm{mi}^{\mathrm{PM}}<\mathrm{mi}^{\mathrm{D}}$.

${ }^{19}$ See Appendix, Part I, Positive Military Investment Equilibrium, (A-9)-(A-11).
} 


\section{A Return to Case Materials}

Returning to the two cases with which we began this analysis - those of medieval England and Kenya - note two implications of our analysis. By linking wealth and the capacity for violence, it suggests a mechanism that might explain the validity of the famous insight of Moore (1966): that in the course of development, agrarian societies come to constitute the locus of political violence. Moore's insight provided the foundations for subsequent work by Wolf (1969), Skocpol (1979), and others (e.g. Scott 1976, Migdal 1975), who sought to explain why, contrary to Marx's predictions, it was the peasantry, rather than the working class, that constituted the revolutionary political force of modern times. Insofar as modernization implies the commercialization of agriculture, and therefore the accumulation of wealth in rural societies; and insofar as property rights in such societies are defended by family and kin, then our analysis helps to provide the link between economic development and the rise of political conflict in the agrarian periphery of the modern world.

A second implication of our analysis is that when development takes place in such societies, there may come a demand for a new source of order. The logic of stateless societies imposes a tradeoff between prosperity and violence. It therefore imposes a frontier that limits the level of well-being attainable in such societies. If people could reconfigure their political institutions, they therefore might be able to escape the logic imposed by the system of self-defense and become better off as a result.

It is therefore suggestive that in both the historical and contemporary period, we find that, seeking to improve their living conditions, members of such societies have indeed attempted to alter their political institutions. Returning to the case of late medieval Europe, we find that the lords and magnates may have, in MacCaffrey's words, invested in the "brutal skills of the armed retainer, half soldier, half gangster" (MacCaffrey 1961, 95), but that they also appeared to have been intensely aware of the costs of so doing. By the time of Richard II, notes Hicks (1995, 128), Parliament repeatedly "pressed for restrictions on liveried companies," even though Parliament was dominated by the very magnates who had organized them. Themselves both perpetrators 
and victims of violence, the lords turned to the Crown and demanded an increased level of law and order. A similar situation appears to have prevailed in France, where local communities called for the "institution of the peace," wherein public officials, rather than private families, would provide political order (Duby 1987, 141). In Genoa, the warring clans joined in contracting for the services of specialists in violence, who would deter domestic conflict and elicit cooperation, the better to secure their fortunes from commerce (Greif 1998). And in what is now Russia, according to a $12^{\text {th }}$ Century chronicler, the Slavs petitioned the Swedes, writing "Our country is rich and immense, but it is rent by disorder. Come and govern us...." (Cohat 1992, 62).

Turning to the modern world, we encounter evidence of similar behavior in Africa. Perhaps most persuasive is the evidence gathered by Colson (1974) from the Plateau Tonga of Northern Rhodesia (now Zambia) at the height of the anti-colonial struggle against colonial rule. Like other African societies, the Tonga strongly backed the nationalist movement; but, Colson (1974) makes clear, they did not seek the overthrow of government. Rather, they sought its capture. For they feared a "return to conditions they remembered when they had to defend themselves for ensuring life and property, rather than on the presence of the district administration, and the more remote central government" (Ibid., 67). They feared a return to the decentralized use of coercion, with the insecurity it unleashed and the costs in terms of benefits forgone or of life and property destroyed. ${ }^{20}$

Our model shows that decentralized systems can provide security; but in doing so they impose a trade off between order and prosperity. These examples suggest that members of such societies have been aware of the limitations imposed upon them and sought an alternative set of political institutions.

\footnotetext{
${ }^{20}$ Notable too is Southall's study of the Alur of northern Uganda which documents their importation of chiefs in an apparent effort to secure "new technologies of peacekeeping, arbitration, and conflict management” (Southall 1956, 80). And Dike (1956), Northrop (1978), Ottenberg (1958) and others (Dike (1956); Northrup (1978); Ottenberg (1958); Jones (1963)) describe how the Aro, specialists in commerce, ritual, and governance, contracted with the decentralized communities of what is now the south east of Nigeria to provide law and order and protection for trade.
} 


\section{Part II: Societies with States}

In order to explore under what conditions societies may choose to reconfigure their political relationships, we return to the model and introduce a figure $\mathrm{G}$, who is a specialist in violence. We then explore the interaction between $\mathrm{G}$, a specialist in violence, and private agents, and seek to identify and characterize the conditions under which such specialists can be tamed, rendering $\mathrm{G}$ a government and the society a state. In pursuing this line of analysis, we address two key questions:

- When can a specialist in violence credibly commit to use its military capabilities to prey only upon economic agents that have themselves attacked others, in effect making coercion economically productive?

- And under what conditions will this governance of violence render economic agents better off than in a world without a state?

To launch the analysis, consider two examples: one, concerning state formation and drawn from late medieval Europe and the other concerning state collapse drawn from modern Africa.

\section{An Example from History}

Returning to the scholarship on late medieval England, we encounter a society fractured by "confederacies, conspiracies, and lawlessness" (Ormrod 1993, 99); armed with their own retainers, the magnates controlled "large retinues with which they could pursue their private feuds..." (Hicks 1995, ix).

As we have seen, even while engaged in such bloodshed, the magnates realized the limits of the private provision of defense for property and viewed it "as a major impediment to the restoration of social and political harmony" (Ormrod 1993, 59) and thus to their own prosperity. Given the limitations inherent in the private provision of property rights, it is therefore informative to find the lords "accept[ing] the legal reforms of Henry II that substituted ... remedies in royal courts for their own courts and jurisdictions" (Hicks 1995, 113). As scholars such as Hicks (1995) and Hudson (1996) make clear, the first step in this transformation was the creation of criminal law: "Violent 
revenge and blood feuds," writes Hicks $(1995,113)$, were now treated as crimes against the common weal.

One of the first steps in the creation of the English state, then, was the banning of private warfare and the centralization of political order: the defense of private rights in property was now to be provided by a specialist, rather than by private parties.

Contemporaneous with this transition was the levying of taxes. Until the late medieval period, monarchs themselves financed their activities, raising funds from their farms and forests and from the tenants who leased their lands. When they began to provide public order, however, they gained access to a new set of revenues: those paid by private parties, who consumed the judicial services of the king. Fees from the judicial system rapidly became a significant source of public revenues (Prestwich 1980, $235 \mathrm{ff}$ ).

It is therefore notable that when Richard I and John Lackland sought increased revenues -- the first to continue his crusades and the second to ransom his brother and to recover lands lost on the continent. -- elites who had previously willingly contributed to the costs of government rebelled. Key to the restoration of order were the terms of the settlement embodied in Magna Carta, which both defined rights in property, limited powers of taxation, and granted the insurgent barons four castles, each in a politically strategic location, to serve as a pledge for the agreement.

The case of England offers insights into the foundation of states. State-based political order, it suggests, arises in a context of (a) the public enforcement of property rights; (b) the pacification of civic society; and (c) the payment of taxes. Because the maintenance of state-based political order rests upon this tripod of taxes, property rights and the demilitarization of private forces, the analysis suggests that if one leg changes without corresponding compensation in the others, then order may collapse.

\section{A Modern Example}

Modern examples provide further insight into the pact between specialists in violence and private agents. In particular they reaffirm the importance of public revenues for keeping the peace: Taxes must not only not be too high (for fear of triggering rebellion by private agents) but also not be too low (for fear of triggering predation by specialists in violence). 
During the global recession of the late $20^{\text {th }}$ Century, the government of Liberia numbered among those hard hit by the crisis in international credit. Given global recession, demand for primary products declined, and Liberia therefore exported lower quantities of iron, rubber, and timber; what it did export, it sold at lower prices. As the majority of the government's revenue derived from trade, the reduction in the value of exports inflicted a major blow to its finances. And when in the 1980s Liberia withdrew its permission for the United States to use its territory for the deployment of military forces, public revenues declined further as the United States withheld further subventions to the government's budget. In an effort to pay its bills, the government of Liberia reverted to printing money. This amounted to an inflation tax, which private agents resisted by eschewing the use of money and moving their exchanges into the barter economy. But those, such as public servants (including soldiers) who produced no commodities and were paid in local currency, could not so shelter their incomes. Thus those who worked for the government suffered a decline in income and living standards.

As in other countries, Liberia's macro-economic crisis therefore became a crisis in public finance. And as in other countries, it became a political crisis as well. Triggering the political crisis was the response of the military to the decline of the public economy. When revenue declined, the incentives for the government to refrain from predation eroded. No longer sufficiently motivated by the value of public revenues to use their coercive capabilities to defend property rights, specialists in violence instead turned predatory. Ordinary soldiers began to harass common citizens. Officers began to force foreign firms to take them on as partners and to extract bribes as part of the cost of doing business (Reno 1998, Ellis 1999).

In turn, private agents stopped paying taxes. Without protection of property rights, output per capita declined as persons withheld resources from productive activities. In addition, private agents shifted resources into the provision of their own defense. In a variety of locations, those who sought to produce for profit began privately to contract for military protection. Some of the larger firms imported security services from abroad. Other, "smaller ... Americo-Liberian and ... Lebanese operations" built "personal connections" with military personnel (Reno 1998, 86). Liberia experienced a 
transition from civilian politics to warlord politics. Political order collapsed (see also Ellis 1999).

The flow of revenues to specialists in violence induces them to refrain from predation and to protect property rights. When public revenues decline, specialists in violence may revert to predation and private agents to self-defense, accelerating political decline and economic collapse. As did the case of England, the case of Liberia suggests that state-based political order rests upon a tripod of demilitarization of kin and community, the protection of property rights, and the payment of taxes.

\section{A Return to the Model}

To capture the forces at play in the empirical record, we return to our model and introduce $\mathrm{G}$, a specialist in violence, into a world, already inhabited, as it were, by private agents who can chose to work, to prepare for battle, or to remain idle. We want to establish condition under which private agents will pay for protection and demilitarize themselves in exchange.

G undertakes no productive labor. Rather, she extracts her income from others; she does so either by raiding the wealth of others or by securing the payment of taxes. After observing the actions taken by private agents, $\mathrm{G}$ chooses whether to prey upon player 1 or player 2 or neither in each period. G's action set therefore is $\mathrm{A}_{\mathrm{G}}=\left\{\left(p_{i}, p_{-i}\right)\right.$ : $p_{i}, p_{-i} \in\{0,1\}$, where $p_{i}$ and $p_{-i}$ cannot both equal 1$\}$. To illustrate: $\mathrm{A}_{\mathrm{G}}=(0,1)$, if $\mathrm{G}$ decides to prey only upon private agent or player $-i$.

As before, each period the private agents (now, citizens) simultaneously decide how to allocate their resources (in the first sub-period) and then whether to raid others in an effort to augment their incomes (in the second sub-period). What distinguishes their action set from that in stateless societies is the existence of a new alternative: citizens can elect to pay taxes to a specialist in violence. Define $t_{i} \in\{0,1\}$ to equal 1 if player $i$ pays taxes and equal to 0 if she does not pay. If a player chooses to pay taxes, she transfers a share, $\tau$, of her income to $G$. The sequence of action each period is thus:

players decide allocations and whether to pay taxes $\rightarrow$ 
players decide whether to raid $\rightarrow$

$\mathrm{G}$ decides whether to be predatory or punish nonpayment or raiding.

Player $i$ 's action set therefore becomes $\mathrm{A}_{i}=\left\{\left(w_{i}, m_{i}, l_{i}, r_{i}, t_{i}\right): w_{i}, m_{i}, l_{i} \geq 0\right.$ and $w_{i}$ $\left.+m_{i}+l_{i}=\mathrm{T}, t_{i} \in\{0,1\}\right\}$ in the first subperiod; her action set in the second sub period is $r_{i}:\left\{w_{i}, m_{i}, l_{i}, t_{i}, w_{-i}, m_{-i}, l_{-i}, t_{-i}\right\} \rightarrow\{0,1\} ;$ and her income, $\mathrm{I}_{i}(\bullet)=\left[\mathrm{F}\left(w_{i}\right)+r_{i} \mathrm{~F}\left(w_{-i}\right) \mathrm{M}\left(m_{i}, m_{-i}\right)\right.$ - $\left.r_{-i} \mathrm{~F}\left(w_{i}\right) \mathrm{M}\left(m_{-i}, m_{i}\right)\right]\left(1-t_{i} \tau\right)\left(1-p_{i} q_{i}\right)$. That is, the private agent $i$ 's net income, $\mathrm{I}_{i}(\bullet)$, includes her revenue from productive labor and raiding; minus taxes, if she chooses to pay; minus the expected reduction in her income resulting from predation by $\mathrm{G}$, should $\mathrm{G}$ decide to expropriate her property.

G's objective is to maximize the net present value of her revenues from taxes and expropriation, discounting for time by a factor, $\delta_{\mathrm{G}}$. For simplicity of exposition, we initially assume that the tax rate is exogenous.

In characterizing the military balance between $\mathrm{G}$ and private citizens, we make three assumptions. Given that private agents are themselves capable of violence, (i) when $\mathrm{G}$ preys upon the economic output of a player $i$, G succeeds in capturing her wealth only in a probability, denoted by $q_{i}{ }^{21}$ (ii) Second, G engages in predatory activity only if the expected revenues from its use of violence exceeds its costs of military activity, denoted by $\mathrm{C}_{\mathrm{G}}$, where $\mathrm{C}_{\mathrm{G}}>0$. (iii) Third, we assume that $\mathrm{G}$ can dispossess only one agent per period.

G's per-period payoff is

$$
\begin{aligned}
& \pi_{G}(\bullet)=\sum_{i}\left\{\left[p_{i} q_{i}\left(F\left(w_{i}\right)+r_{i} F\left(w_{-i}\right) M\left(m_{i}, m_{-i}\right)-r_{-i} F\left(w_{i}\right) M\left(m_{-i}, m_{i}\right)\right)(1-t \tau)\right]+\right. \\
& \left.\left[t_{i} \tau\left(F\left(w_{i}\right)+r_{i} F\left(w_{-i}\right) M\left(m_{i}, m_{-i}\right)-r_{-i} F\left(w_{i}\right) M\left(m_{-i}, m_{i}\right)\right)\right]\right\}-C_{G}\left(p_{i}+p_{-i}\right)
\end{aligned}
$$

for $i=1,2$.

The first bracketed elements in the equation represent G's revenue from expropriating private agents' wealth, if $\mathrm{G}$ decides to engage in predation. If $\mathrm{G}$ dispossesses agent $i, p_{i}=1, \mathrm{G}$ 's expected (gross) revenue from that action equals the 
probability of successful predation, $q_{i}$, multiplied by player $i$ 's income from work and raiding, net the amount she has paid in taxes. The second term in G's payoff function is the amount of tax paid by each private agent who has chosen to do so. Finally, if $\mathrm{G}$ decides to prey upon the wealth of either agent, that is, if $p_{i}+p_{-i}>0$, then $\mathrm{G}$ has to bear the cost of the predatory activity, $\mathrm{C}_{\mathrm{G}}\left(p_{i}+p_{-i}\right)_{i}>0$.

By limiting the power of $\mathrm{G}$, our model does not take political order for granted but rather allows it, under certain conditions, to emerge. ${ }^{22}$ Employing this framework, we isolate the conditions under which there can exist an equilibrium in which private agents abide by a self-enforcing contract with a specialist who employs violence to protect productive activity. In particular, we explore the conditions that support a cooperative governance equilibrium, under which the specialist in violence is tamed and a state can be said to exist.

\section{Analysis}

As in the case of our model of a stateless society, we let the agents choose in a utility maximizing manner and explore the properties of the equilibria that may result. The results capture the interrelationships between taxation, property rights, private

\footnotetext{
${ }^{21} q_{i}$ can reflect player $i$ 's ability to evade G's "troops" or confront them using her military power, $m_{i}$. For simplicity sake we do not specify $q_{i}$ as a function of $m_{i}$.

22 These premises lead us to depart from sociological conceptions of the state (e.g. Weber 1958) and to analyze the foundation of the state using game theoretic forms of analysis. Other relevant contributions include (Grossman 1997), who utilizes a general equilibrium, static model to explore the technological conditions under which economic agents will "hire" a state to protect them from outside predators although ex-post the state will tax them to maximizes its benefits. Moselle and Polak (1999b) explore the interrelationships between states and bandits and demonstrates that the state can reduce welfare when economic agents lack military power. Usher (1989) considers economic agents as possessing no military capabilities and examines the welfare effects of dynastic cycles and rebellions. Elbadawi (1999) and Azam (1994) are similarly concerned with the implications of potential rebellion and external threats. See also Konrad and Skaperdas 1996.

${ }^{23}$ These premises lead us to depart from sociological conceptions of the state (e.g. Weber 1958) and to analyze the foundation of the state using game theoretic forms of analysis. Other relevant contributions include (Grossman 1997), who utilizes a general equilibrium, static model to explore the technological conditions under which economic agents will "hire" a state to protect them from outside predators although ex-post the state will tax them to maximizes its benefits. Moselle and Polak (1999b) explore the interrelationships between states and bandits and demonstrates that the state can reduce welfare when economic agents lack military power. Usher (1989) considers economic agents as possessing no military capabilities and examines the welfare effects of dynastic cycles and rebellions. Elbadawi (1999) and Azam (1994) are
} 
demilitarization and the formation and disintegration of the state observed in the examples above. They suggest that:

- That public revenues help to harness the specialist in violence, as tax payments induce $\mathrm{G}$ to use her coercive capabilities to protect property rights rather than to engage in predation.

- That there exists an optimal tax rate. The level must be sufficiently high to restrain predation and sufficiently low to forestall a return to the private provision of violence.

- That the incentives for $\mathrm{G}$ to refrain from predation are a function of its prospective payoffs off-the-equilibrium path, and that these payoffs help determine whether a tax rate exists that private agents are willing to pay and that $\mathrm{G}$ finds sufficiently attractive to induce it to refrain from predation.

Analysis of the comparative statics further suggests that order can collapse following:

- A lowering of the governments discount factor and a rise in its insecurity.

- An increase in the prospects of the governments off-the-equilibrium path.

- A change in the relative military capabilities of governments vis-à-vis private agents.

- A rise in productivity without an increase in public revenues.

We begin by exploring the properties of a cooperative governance equilibrium (CG). The strategy profile for the CG equilibrium (described in detail in the appendix) calls for each private agent to select $w_{i}{ }^{\mathrm{CG}}, m_{i}{ }^{\mathrm{CG}}, l_{i}{ }^{\mathrm{CG}}$ optimally (given the strategies of other players), not to raid, and to pay taxes to $\mathrm{G}$ if the other agent did not raid and $\mathrm{G}$ has never seized the wealth of a private agent. Otherwise, the private agent "revolts," refuses to pay taxes and reverts to self defense, playing what we call the warlord equilibrium (WL) strategy (described below) over subsequent periods. For its part, in equilibrium, G refrains from confiscating property as long as neither private agent raids or fails to pay her taxes. If either agent raids or fails to pay her taxes, $\mathrm{G}$ then becomes predatory; it begins to behave as a warlord, seizing the wealth of the private agents. Predation and 
violence are deterred by the threat of permanent reversion to the warlord equilibrium, ${ }^{24}$ which is characterized by predation by $\mathrm{G}$ and low levels of output, as private agents seek security by investing in military preparedness or by remaining poor.

\section{Taxes as Inducements on the Equilibrium Path}

G's incentive to remain on the equilibrium path derives from the revenues she can secure from taxation. To induce $\mathrm{G}$ to refrain from predation (i) the tax level, $\tau$, needs to be high enough that $\mathrm{G}$ finds it optimal, given the private agents' strategy, to refrain from confiscating the agents' wealth if taxes are in fact paid. ${ }^{26}$ A second condition must also be satisfied: (ii) G must find it profitable to punish any agent who raids or fails to pay taxes. In other words, the cost to $\mathrm{G}$ of punishing must not exceed the amount it would expect to gain from expropriating the property of a transgressing agent. ${ }^{27}$

An intriguing property of this equilibrium is that while the tax level must be sufficiently high to induce $\mathrm{G}$ to remain on the equilibrium path, it cannot be too high. For not only might private agents then regard self-defense as an attractive alternative; but also they might regard as incredible G's threats of punishment. When G punishes private agents who fail to pay taxes, its predatory behavior then triggers a reversion to the warlord equilibrium. But should $\mathrm{G}$ refrain from punishment, the strategy of the private agents then calls for them to pay taxes. Should tax payments be high, then the private agents might reasonably view $\mathrm{G}$ as being tempted to refrain from punishment, preferring to be a prosperous government than a relatively impoverished warlord. The level of tax payments that sustain the cooperative government equilibrium is thus bounded from above as well from below. In this sense, the conditions that support the equilibrium are knife edged. ${ }^{28}$

Skaperdas 1996.

${ }^{24}$ See Appendix, Part II, Cooperative Governance Equilibrium, (A-15)-(A-20).

${ }^{26}$ See Appendix, Equation (A-15).

${ }^{27}$ See Appendix, Equation (A-15). These conditions are necessary; exploring the sufficient conditions for these strategies to constitute an equilibrium complicates the presentation without generating additional insights.

${ }^{28}$ This discussion suggests an extension to the model, allowing the tax rate to be endogenously determined. Say the tax rate were set by G's decree (of course, the private agents can choose to pay any fraction of the 
On the equilibrium path, the private agents' strategy requires that they not raid each other. But G's threat to revert to predatory behavior may not necessarily be sufficient to elicit such behavior (e.g., if $q$ is too low). Hence, a third condition necessary for the equilibrium (iii): Each private agent must chooses a level of work such that, when coupled with G's strategy, the other agent finds it optimal to invest in the equilibrium level of military ability and not to raid..$^{29}$

\section{Off the Equilibrium Path: Reversion to a Warlord Equilibrium}

While the steady flow of tax payments provides a positive check to the predatory behavior of the specialist in violence, the threat of reversion to stateless-ness provides a negative one. Should the specialist in violence loot a subject, then the citizens revert to providing their own defense and stop paying taxes. They revert to what we call the warlord equilibrium. ${ }^{30}$

The warlord equilibrium differs from the all-defect equilibrium for private agents because G's predatory behavior now figures into private agents' decisions of how best to allocate their resources between work, leisure and military effort. Under this equilibrium, each private agent raids, the specialist in violence $(\mathrm{G}$, acting like a warlord and no longer like a government) engages in predatory confiscation of property by randomly raiding an agent each period, and no taxes are paid. The resultant payoffs constitute the continuation value of the game, should someone defect from the cooperative governance equilibrium.

In the warlord equilibrium, people devote more resources to military preparedness and leisure, responding to and seeking to deter predation by fellow citizens - and by the specialist in violence, now on the prowl - than they do in the cooperative governance equilibrium. Productive efforts decline, resulting in less total output. Should she behave

\footnotetext{
tax and elect to suffer any consequences): in this case, were $\mathrm{G}$ to demand too high a tax, then G's threat of predation if the demand were not met, would not be credible. The agents could safely pay the lower rate defined by condition (i) knowing that this amount will be enough to dissuade $\mathrm{G}$ from preying on their property.

${ }^{29}$ See Appendix, Equations (A-17)-(A-18).

${ }^{30}$ See Appendix, Part II, Warlord Equilibrium, (A-21)-(A-23).
} 
opportunistically, the specialist in violence would therefore trade a steady flow of revenues, paid in the form of taxes, for the short-term benefit of loot - and the long term prospect of having to seize prizes from a society that is now better armed and less wealthy, and hence more costly and less rewarding to plunder.

Because the threat of reversion to warlordism helps to keep both the government and citizens on the equilibrium path, G's continuation value, ${\partial_{\mathrm{G}}}^{\mathrm{WL}}$, constitutes a critical parameter in restraining the behavior of the specialist in violence. If $\mathrm{\partial}_{\mathrm{G}}{ }^{\mathrm{WL}}$ is high, the taxes needed to induce $\mathrm{G}$ to behave as a government may also be high so as to make governance unattractive. And this would be the case even though the level of tax payments might be too low to make it profitable for $\mathrm{G}$ to foreswear arbitrary predation. ${ }^{31}$

\section{Part III: Comparative Statics, Political Collapse, and the Warlord Equilibrium}

Our examination of the cooperative governance equilibrium thus suggests that the prospects of political order are influenced not only by the level of public revenues but also by the government's assessment of its prospects should order break down. G's future prospects off-the-equilibrium path are determined by (i) $\delta_{\mathrm{G}}$, the extent to which $\mathrm{G}$ values future payoffs and (ii) $\partial_{\mathrm{G}}{ }^{\mathrm{WL}}, \mathrm{G}$ 's continuation value payoff. By affecting the possibility of order, these conditions also affect the likelihood of a transition to warlord politics. $^{32}$

$\delta_{\mathrm{G}}$ : Should G's discount factor $\left(\delta_{\mathrm{G}}\right)$ fall, future punishments are more heavily discounted and the immediate payoffs of opportunistic defection become more alluring. ${ }^{33}$ If members of civic society are unwilling to compensate by increasing their payment of taxes, the specialist in violence's best response is to revert to predatory activity. Its actions would then trigger the break down of political order, but it would willingly assume future losses because they are highly discounted. Given a fall in their discount

\footnotetext{
${ }^{31}$ See Appendix, Part II, Comparative statics for the CG Equilibrium.

${ }^{32}$ See Appendix, Part II, Comparative statics for the CG Equilibrium.

${ }^{33}$ Returning to the conditions necessary for the cooperative governance equilibrium, the tax payments necessary to sustain the equilibrium (i) may rise to the point where they violate condition (iv).
} 
factor, incumbent specialists in violence might therefore be tempted to engage in acts of predation that lead to the breakdown of states.

$\partial_{\mathrm{G}}{ }^{\mathrm{WL}}$ : Should the government's prospects as a warlord, ${\partial_{\mathrm{G}}}^{\mathrm{WL}}$, improve, even in the midst of disorder, $\mathrm{G}$ would feel less threatened by the breakdown of orderly governance -- and therefore more willing to engage in predation.

q: Also influencing the prospects of the government should order break down is (q), the government's relative capacity to fight and thus to seize the citizens' resources. Should G's ability to extract income from private agents rise, her incentives to uphold her end of the governance bargain will fall unless compensated by a higher tax rate.

Similarly, holding q constant, suppose there is a change in technology such that output increases for each unit of labor input. The analysis suggests greater taxes will then be required to maintain a cooperative governance equilibrium. Phrased another way, G will demand a higher "bribe" to refrain from predation.

\section{The Discount Factor}

To explore these implications, we return to case materials and begin with changes in the discount factor. ${ }^{34}$ We first explore the collapse of the Soviet Union and then turn to the introduction of democracy in Africa and to the recent growth of disillusionment arising from the perceived increase in corruption, predation, and violence.

The Former Soviet Union: When Gorbachev legalized the formation of opposition parties and opened legislative and executive positions to electoral competition, Klebnikov $(2000,57)$ reports, the specialists in violence - elite officials in the communist party and the security services - proclaimed a "period of emergency." Since their future in office was no longer assured, they began looting state enterprises, firms that extracted natural resources, and public funds that had been deposited in the banking system. In response, other agents began to withhold resources from the state. By late 1991, Treisman (1999) reports, one third of the countries' regions had stopped paying taxes to

\footnotetext{
${ }^{34}$ See Appendix, Equations (A-24)-(A-25).
} 
the center (p. 2). Shleifer and Triesman (2000) describe similar levels of non-payment by firms. "Federal public finances" fell into "crisis," Shleifer and Treisman (2000, 89) report, with "tax collections [falling] from about 18 percent of GDP in 1989 to about 11 percent in 1996."

Not only did non-governmental actors withhold finances from the state; they also began to provide their own defenses. In the spring of 1993, Boris Yeltsin declared that two thirds of all commercial enterprises in Russia had links to organized crime, (quoted in Klebnikov 2000, 29). And first throughout the USSR and then throughout the Russian Federation, republics began to declare themselves sovereign entities (see Triesman 1999), and thus entitled not only to the levying of their own revenues but also to the creation of their own military forces. Society remilitarized, decentralizing control over the means of coercion.

The response to political reform in the former Soviet Union thus provides evidence that suggesting that the foreshortening of time horizons can precipitate plunder and official corruption, spurring a fiscal crisis and the breakdown of political order.

Democratization in Africa: By the mid-1980s, a consensus had grown that politics lay at the root of Africa's development problems (see the review in Ndulu and O'Connell 1999). Both international donors (e.g. World Bank (1991)) and domestic elites (e.g. Ake (1990)) therefore called for political reform. But many have since become disillusioned with the outcome. A rise in corruption; an increases in ethnic and regional strife; and in some cases the collapse of the state appear to have accompanied political reform. In light of the reasoning formalized in our model, the failures are consistent with what might be expected, when incumbents raise the rate at which they discount future payoffs.

Anecdotal evidence serves to highlight the point. Tanzania, once a model of political probity, became increasingly corrupt in the late 1980s. Many attribute the change in the behavior of public servants to a change in the "culture" of TANU, the ruling party, which now faced the prospect of the loss of power in competitive multiparty elections (Interviews 1992). Zambia in the late 1980s presents another example: UNIP, long the official governing party, created a "pension plan", forcing the government to 
divert funds from projects and public servants to party activists, who, with democratization, now faced the possibility of loosing power (see Bates and Collier 1991).

More systematic is the evidence of Block, Ferree and Singh (2000), who document the existence, significance, and magnitude of "political business cycles" in African politics. They find evidence of the largest cycles in countries that allow electoral competition and that therefore possess governments that face the greatest prospects of losing office. Standard explanations of political business cycles emphasize incumbents' desire to win elections, but in Africa they can also be read as the destruction of private wealth in response to the prospects of losing power. Further evidence comes from McMillan and Masters (2000), who in a cross sectional study of the agricultural policies of African states relate measures of political instability to inefficiently high levels of taxation of export crops.

Those expressing reservations about the impact of democratization also point to the outbreak of violence, as political elites began to mobilize regional and ethnic forces while competing for political office. "Democratization," Sisk and Reynolds (1998, 29) declare, "more often than not increases ethnic nationalism and generates ... deadly conflicts." The conviction has grown that electoral competition promotes a "'winnertake-all' approach to politics," with incumbents using their office to engage in plunder (Ibid., 29). So great are the perceived costs of democratization, they report, that "Western governments [began to pull] back from their ... pursuit" of political reform in Africa (Ibid., 11).

In the latter decades of the $20^{\text {th }}$ Century, scholars and policy makers alike endorsed democratization as a development strategy for Africa. Political reform has disappointed many of its initial champions, however. While we, too, are disappointed by the outcome, given the logic of our analysis, we are not surprised. In Prezworski's pithy phrasing $(1991,11)$, “democracy is a system in which parties lose elections." And our analysis suggests that in the early stages of democratization an increase in uncertainty for incumbent elites can be expected to bring, ceteris paribus, increased levels of political predation and an increased possibility of violence. 


\section{The Continuation Value of the Game}

Also affecting the willingness of a government to remain on the equilibrium path is its discount factor $\left(\delta_{\mathrm{G}}\right)$. Should a specialist in violence be impatient, it may be less constrained in its use of violence by the bleakness of future prospects, it may therefore be more willing, all else being equal, to seek short term gains even at the cost of precipitating future disorder. The same logic implies that, holding the discount factor $\left(\delta_{\mathrm{G}}\right)$ constant, specialists in violence who face better prospects in the period of political breakdown $\left(\partial_{\mathrm{G}}{ }^{\mathrm{WL}}\right)$ might be more willing to engage in behavior that threatens their pact with private citizens. ${ }^{35}$ One factor that could influence the prospects of specialists in violence/governments off-the-equilibrium path $\left(\partial_{\mathrm{G}}{ }^{\mathrm{WL}}\right)$ would be independent access to sources of wealth, and thus their capacity to prosper, even when citizens withhold taxes. In exploring the impact of this factor, we therefore turn to the literature on the oil producing states of the Middle East.

As is notorious, the recent "third wave" (Huntington 1991) of democratization bypassed the Middle East. In doing so, it presented a puzzle for political analysis. Seeking an explanation for this seeming regional resistance to political reform, scholars developed the notion of the "rentier state." (e.g. Andersen 1986; Beblawi and Giacomi 1987; Chaudry 1997; Mahdavy 1970)

States that possess access to flows of income from precious resources, these scholars argue, need not raise taxes from their citizens, and therefore need not bargain with them. Hence these governments feel less compelled to surrender to citizens the right to convene legislative assemblies, to form opposition parties, or to compete for public office. It is therefore noteworthy that Michael Ross (Ross 2000), studying the politics and economics of 105 states over the period 1971-1997, finds that those endowed with minerals and oil are more likely to be autocratic and less likely to be democratic than are others. By implication, being less accountable and facing fewer political constraints, rulers in such societies can employ their powers in a more predatory fashion.

\footnotetext{
${ }^{35}$ See Appendix, Part II, Comparative statics for the CG Equilibrium.
} 
Our argument provides an alternative interpretation of these findings. It suggests that because the governments possess independent sources of income in the form of revenues from oil fields and mineral deposits, they fear less the reaction of citizens, were they to behave in predatory fashion. And realizing that they cannot afford to bribe their governments to behave in a more restrained manner, citizens, for their part, have less of an incentive to pay taxes to their governments.

Both our model and the "rentier states" explanation predict abundant natural resources, low levels of tax payments as a percent of government revenues, and high levels of authoritarianism would go together. An advantage of our model, however, is that it suggests additional relationships that should prevail in the empirical record. Our logic suggests predatory behavior unleashes the private provision of defense and we should therefore expect that, in response, resource rich governments would themselves militarize. We should expect them to spend proportionately more on their security forces. And, indeed, Ross (2000) finds that governments in such states do spend a greater percentage of their incomes on weapons. ${ }^{36}$

The logic of our argument leads us also to expect societies richly endowed with oil and mineral wealth to experience higher levels of domestic violence. It is therefore interesting that Collier and Hoeffler (1998) find that states more abundantly endowed with natural resources experience a significantly higher likelihood of civil war. Lastly, our logic would imply that, with property rights insecure and persons reallocating resources from production to the defense of their incomes and property, the rate of growth would be low, even though the economy is richly endowed. And indeed, Sachs and Warner (1995; 1999) have published evidence confirming the existence of this anomaly.

Our argument thus provides an alternative explanation of the "stylized facts" captured in the writings on "rentier states." While doing so, it generates additional implications concerning the level of militarization, conflict, and growth -- implications that find confirmation in the literature. 


\section{Military Technologies}

Also influencing the properties of a governance pact is the specialist in violence's relative military capabilities vis-à-vis the private agents, captured by the parameter $q$. Should the offensive capabilities of the government rise relative to the defense of the private agents (that is, should $q$ rise in value), then the level of tax payments necessary to stay the hand of the specialist in violence would rise. Should, however, the defense become advantaged, then the equilibrium level of tax payments could decline, as the specialist would perceive less favorable prospects following the collapse of political order. $^{37}$

Reflecting upon these implications, we are drawn once again to history, and specifically to the rise of the city in medieval Europe. The first wave of urbanization centered in northern Italy. Pioneering new techniques in commerce, banking, and finance, and benefiting from the withdrawal of Muslim and Byzantine navies from the Mediterranean, Venice and the cities of Lombardy rapidly became the most prosperous region in $12^{\text {th }}$ Century Europe. The Holy Roman Empire therefore renewed its claim to what the German Bishop Otto of Freising, the chronicler of the Emperor Barbarossa, considered to be a "very garden of delights" that "surpassed all other states of the world in riches" (Munz 1969, 126). In the Decree of Roncaglia in 1158, Barbarossa, assigned a higher tax burden to the prosperous cities of North Italy while pledging to punish cities that attacked other cities or that refused to pay taxes (see Munz 1969; Tabacco 1989; Waley 1988). ${ }^{38}$

Barbarossa's efforts soon came undone, however. Employing their wealth, the cities enhanced their defenses, building walls, moats, and elaborate fortresses. In terms of our model, their actions shifted the parameter q. With the improvement of fortifications, the military balance now favored the defense (see Parker 1991, 7) -

\footnotetext{
${ }^{36}$ It is notable that Ross (2000) controls for region, and in particular for location in the Middle East, thus eliminating geopolitical considerations as a possible explanation for this relationship.

${ }^{37}$ See Appendix, Equation $(A-27)$.

${ }^{38}$ See Appendix, Equation $(A-26)$.
} 
something Barbarossa himself learned when forced to spend two years in a siege of Milan.

When Barbarossa attempted to re-assert his power over the urbanized regions of Northern Italy, then, he encountered two forces at play; and these forces worked at cross purposes. One was the rise in urban wealth, which, by our reasoning, would trigger, in equilibrium, a higher level of taxes to deter the specialist in violence from raiding his subjects. ${ }^{39}$ The other was a shift in military technology (i.e. a decline in q) that made defense more effective, implying (by the logic of our argument) a lower equilibrium rate of tax payments. ${ }^{40}$ Barbarossa acted to secure an amount of tax that he regarded as "rightfully his own," in the words of his biographer (Munz 1969, 8). But he failed to appreciate the magnitude of the forces pushing in the opposite direction. The result was a standoff, as Barbarossa sought to extract revenues from Northern Italy and the city-states resisted (Munz 1969, 361-2).

The city-states of Northern Italy proved to be too powerful to find persuasive the Emperor's threats. But they were also too rich to be both peaceful and stateless. Having successfully rebuffed the Emperor's efforts to establish centralized governance, the citystates behaved as productive agents who privately controlled the means of coercion. The region descended into warlordism and chaos.

\section{Conclusion}

In this article, we have advanced a line of reasoning that probes the foundations of political order. The logic of the analysis captures the nature of political order in stateless societies. Stateless societies trade off production and protection, we have argued; in societies with states, both are attainable, and people can therefore live at a higher level of welfare. As captured in the conditions of the cooperative governance equilibrium, the circumstances under which they can do so are tightly constrained. Our analysis of those

\footnotetext{
${ }^{39}$ See Appendix, Equation (A-26).

${ }^{40}$ See Appendix, Equation (A-27).
} 
circumstances therefore generated insights not on only into the possibilities of order, but also into the sources of political breakdown.

In advancing this analysis, we have provided illustrations and examples. The interplay between formal logic and case materials suggests that the reasoning is insightful, however. It also suggests that the reasoning may be powerful. The model is simple, but its implications range widely over time - from the medieval era to the contemporary period - and space - from England to Russia and to Africa. We fully acknowledge that we have not explored controlled comparisons, nor generated a sample of cases upon which we could conduct statistical analyses. But the arguments are in principle testable; indeed, we have begun preparation for testing.

In closing, we note that the implications of this analysis are normative as well as positive in nature. At first glance, they appear starkly Hobbesian (Hobbes 1947). When security is privately provided, and there is no "Sovereign," people, it suggests, lack the incentives to engage in productive labor. As put by Hobbes, "where an Invader hath no more to feare, than another man's single power," then "if one plant, sow, build, or possess a convenient Seate, other may ... be expected to come prepared with forces united to dispossesse (Hobbes 1946, bk 13, par. 61). And with the "continuall feare and danger of violent death," then there is "no place for industry ... no Culture of the Earth; no Navigation, nor use of the commodities that may be imported by Sea; no commodius Building ..."(Ibid., bk 13, par. 62).

Upon further reflection, however, it becomes clear that rather than confirming Hobbes' portrayal of life in a society without a state, we in fact amend it. For our argument implies that societies in he state of nature can be rich; but for them to be so, citizens must also invest in the capacity for violence.

Even more interesting are the implications for societies with states. For our analysis suggests when coercion is organized, then society can (in the limit) can secure as an equilibrium an allocation of resources makes possible the attainment of the first best level of welfare. The state, this finding suggests, can serve as an instrument for the enhancement of the social welfare. Recall that the logic of our analysis highlights two sources of welfare loss. One is violence: private agents will shift effort from productive 
activities to military preparedness or to leisure in an effort to discourage raiding by others. The other is taxation: private agents will shift effort from productive activities to leisure because $\mathrm{G}$ (the government) taxes them. The first source of inefficiency occurs both in societies with and without states. The second is, of course, unique to societies with states. ${ }^{41}$

The magnitude of the welfare loss inflicted by governments depends upon the level of taxation necessary to deter them from breaking their pact with private agents. And the level of taxation required to induce compliance by specialists in violence is a function of the prospects they face should they abandon the pact and forage for income on their own. In light of our discussion, we can classify governments into those that possess positive prospects in the state of disorder that will prevail when they abandon their obligations to their citizens (either by preying upon their assets or by failing to punish those who do) and those that do not.

As demonstrated in the appendix, the government's time horizon lengthens, the level of taxation necessary to induce it to provide protection for property rights declines. Indeed, in the limit (i.e. as $q_{I}$ approaches 1 and $\delta_{\mathrm{G}}$ approaches 1 ), for governments with no positive prospects under conditions of warlordism $\left(\partial_{\mathrm{G}}{ }^{\mathrm{WL}} \quad 0\right)^{42}$, the level of taxation necessary to keep on the cooperative governance equilibrium path goes to zero. The result is the end of the distortion of economic incentives and elimination of welfare loss. The implication is clear: when coercion is organized, then society can (in the limit) secure an allocation of resources that, in equilibrium, generates a level of welfare that approaches the first best.

This finding underscores our argument that governments can render coercion socially productive. It also highlights that societies ruled by specialists in violence can do at least as well as societies in which coercion is privately provided. Indeed, although the first best may unattainable by either society, societies with states can achieve peace and prosperity in the limit. The most efficient equilibrium in the game with $\mathrm{G}$ supports a

\footnotetext{
${ }^{41}$ See Appendix, Part II, Welfare Implications of CG equilibrium.

${ }^{42}$ By no positive prospects off-the-equilibrium path, we refer to a non-positive payoff in the warlord equilibrium (or off cooperative governance equilibrium path).
} 
higher level of welfare than the most efficient equilibrium in the game without $\mathrm{G}$ in which there is no violence.

It is a virtue of our analysis that normative issues can be addressed within the same framework as that which we bring to bear upon qualitative accounts of politics. 


\section{Appendix}

\section{Part I: Stateless Societies}

\section{First Best Equilibrium in a Repeated Play Game}

For $i=1,2$ and $\delta_{\mathrm{i}} \in[0,1]$, there exists $\delta^{*}{ }_{\mathrm{i}}$ such that, $\forall \delta_{\mathrm{i}} \quad \delta_{\mathrm{i}}{ }_{\mathrm{i}}$, the first best outcome can be sustained in as a symmetric, sub-game perfect Nash equilibrium (SPNE).

Consider the following strategy profile, $\sigma^{\mathrm{FB}}$, for each player $i$ : Play $w_{i}^{\mathrm{FB}}, l_{i}^{\mathrm{FB}}$, $m_{i}{ }^{\mathrm{FB}}=0$, and $r_{i}=0$ as long as the other player has neither raided nor deviated from the first best allocations, and play the one-shot sub-game perfect Nash equilibrium (the all defect strategy) otherwise. Because no deviation from the one-shot sub-game perfect Nash equilibrium is profitable, to show that the above strategy combination is an equilibrium in the repeated game, it is sufficient to show that no player can gain from deviating by raiding given the first best allocations. Thus, the $\sigma^{\mathrm{FB}}$ strategy combination is a SPNE, iff for $\mathrm{i}=1,2$ :

$$
\frac{\pi_{i}^{F B}}{\left(1-\delta_{i}\right)} \geq \pi_{i}^{D, F B}+\frac{\delta_{i} \pi_{i}^{D}}{\left(1-\delta_{i}\right)}
$$

where ${\partial_{i}}_{i}^{D, F B}$ is the payoff for defecting from the first best strategy while the other player maintains the first best allocations, and

$$
\begin{aligned}
& \pi_{i}^{D, F B}\left(w_{i}, m_{i}, l_{i}=T-w_{i}-m_{i}, r_{i}=1, w_{-i}^{F B}, m_{-i}^{F B}=0, l_{-i}^{F B}=T-w_{i}^{F B}, r_{i}=0\right) \\
& =\max _{w_{i}, m_{i}} U\left(F\left(w_{i}\right)+F\left(w_{-i}\right) M\left(m_{i}, m_{-i}^{F B}=0\right), l_{i}\right)
\end{aligned}
$$

Equation (A-1) can be re-written as $\frac{\pi_{i}^{F B}-\delta_{i} \pi_{i}^{D}}{\left(1-\delta_{i}\right)} \geq \pi_{i}^{D, F B}(A-3)$. The RHS of equation (A-3) is finite, but the LHS approaches infinity in the limit: $\frac{\pi_{i}^{F B}-\delta_{i} \pi_{i}^{D}}{\left(1-\delta_{i}\right)} \rightarrow \infty$, as $\delta_{i} \rightarrow 1$. Therefore, there exists $\delta^{*}{ }_{i}$, such that $\forall \delta_{i}>\delta_{i}^{*}$, equation $(A-3)$ holds.

Thus, in the infinitely repeated game, the first best allocation can be achieved as a SPNE if the players are sufficiently patient (with $\delta_{i}$ sufficiently close to 1 ).

Note: Restrictive conditions must prevail, however, for the first best equilibrium to hold even in an infinitely repeated game. Just as the payoffs to the sub-game can be held constant, while varying $\delta_{i}$, so too can the discount factor be held constant, while varying the payoffs to the sub-game. Returning to equation $(A-3)$, it can readily be seen that for any time discount factor, $\delta_{i}$, there is some defection payoff, ${ }_{i}{ }_{i}^{D, F B}$, for which the first best allocations cannot be a SPNE. To maintain the first best as a SPNE when the defection payoffs increase, the players must become more patient. In other words their time discount factor must increase. If $\delta_{i}{ }^{\prime}$ is the lowest value of $\delta_{i}$ for which equation $(A-3)$ 
holds and the RHS of (A-3) increases, then ceteris paribus $\delta_{i}{ }^{\prime}$ must also increase for $(A-3)$ to hold.

\section{Sub-game Perfect Nash Equilibria in a Single Shot Game: All-Defect Equilibrium}

By the Kakutani theorem, an equilibrium exists and we assume it is symmetric. Denote the associated strategy profile with the all-defect equilibrium in the first sub period, $\sigma^{\mathrm{D}}=\left\{\left(w_{i}^{\mathrm{D}}, m_{i}^{\mathrm{D}}, l_{i}^{\mathrm{D}}\right): w_{i}^{\mathrm{D}}, m_{i}^{\mathrm{D}}, l_{i}^{\mathrm{D}} \quad 0\right.$ and $\left.l_{i}^{\mathrm{D}}=\mathrm{T}-m_{i}^{\mathrm{D}}-w_{i}^{\mathrm{D}}\right)$, for $\left.i=1,2\right\}$. In the second sub period, for $i=1,2, r_{i}{ }^{\mathrm{D}}=1$ or $r_{i}^{\mathrm{D}}=0$. That is, either both players raid or not. In either case for $i=1,2, w_{i}^{\mathrm{D}}, m_{i}^{\mathrm{D}}, l_{i}^{\mathrm{D}}$ are player i's best response iff

$$
\left(w_{i}{ }^{D}, m_{i}^{D}, l_{i}^{D}\right) \in \arg \max _{w_{i}, m_{i}, l_{i}} U\left(F\left(w_{i}\right)+F\left(w_{-i}^{D}\right) M\left(m_{i}, m_{-i}^{D}\right)-F\left(w_{i}^{D}\right) M\left(m_{-i}^{D}, m_{i}\right), l_{i}\right)
$$

subject to $w_{i}+m_{i}+l_{i}=\mathrm{T}$ and $w_{i}^{\mathrm{D}}, m_{i}^{\mathrm{D}}, l_{i}^{\mathrm{D}} \quad 0$. The first order conditions imply that in equilibrium, for $i=1,2$ :

$$
\frac{\partial F\left(w_{i}^{D}\right)}{\partial w_{i}}-\frac{\partial F\left(w_{i}^{D}\right)}{\partial w_{i}} M\left(m_{-i}^{D}, m_{i}^{D}\right)=F\left(w_{-i}^{D}\right) \frac{\partial M\left(m_{i}^{D}, m_{-i}^{D}\right)}{\partial m_{i}}-F\left(w_{i}^{D}\right) \frac{\partial M\left(m_{-i}^{D}, m_{i}^{D}\right)}{\partial m_{i}}
$$

Note: If equation (A-5) was an inequality such that the RHS is greater than the LHS, then player $i$ 's best response would be to acquire more military ability and to use it in raiding, and vice versa.

\section{No Military Investment Equilibrium}

The NM strategy profile, $\sigma^{\mathrm{NM}}$, calls for player $i$ to devote $w_{i}^{\mathrm{NM}}$ units of resources to productive work and T $-w_{i}{ }^{\mathrm{NM}}$ units to leisure with no resources allocated to $m_{i}$, as long as the other player has never raided or produced more than $w_{-i}{ }^{\mathrm{NM}}$; and to revert to the $\mathrm{D}$ equilibrium strategy otherwise.

Define ${{ }_{i}}_{i}^{\text {D,NM }}$ as the highest one period payoff that player $i$ can achieve by deviating from the NM strategy (while the other player follows her NM strategy). That is,

$$
\pi_{i}^{D, N M}(\bullet)=\max _{w_{i}^{D, N M}, m_{i}^{D, N M}, l_{i}^{D, N M}} U\left(F\left(w_{i}^{D, N M}\right)+F\left(w_{-i}^{N M}\right) M\left(m_{i}^{D, N M}, m_{-i}^{N M}\right), l_{i}^{D, N M}\right)
$$

Following the same procedure employed with respect to the first best, we can easily verify that the NM strategy combination is a (symmetric) sub-game perfect equilibrium, iff

$$
\frac{\pi_{i}^{N M}}{\left(1-\delta_{i}\right)} \geq \pi_{i}^{D, N M}+\frac{\delta_{i} \pi_{i}^{D}}{\left(1-\delta_{i}\right)}
$$

Equation (A-7) can be rewritten as $\frac{\pi_{i}^{N M}-\delta_{i} \pi_{i}^{D}}{\left(1-\delta_{i}\right)} \geq \pi_{i}^{D, N M}$ (A-8).

Note: The $w_{i}{ }^{\mathrm{NM}}$ level of work is the highest level that can be sustained without inducing military investment. If the other player were to devote more than $w_{-i}{ }^{\mathrm{NM}}$ to work, 
player $i$ would find it rational to devote some units of resources to $m_{i}$ since the marginal productivity of military expenditure would increase. If player $-i$ devoted more than $w_{-i} \mathrm{NM}$ to work, the RHS of $(A-8)$ rises, ceteris paribus, the incentives to behave in ways necessary to sustain no military investment as an equilibrium decline.

\section{Positive Military Investment Equilibrium}

Let each player's positive military investment (PM) strategy profile, $\sigma^{\mathrm{PM}}$, entails investing $m_{i}^{\mathrm{PM}}$ units of effort to military ability (where $0<m_{i}^{\mathrm{PM}}<m_{i}^{\mathrm{D}}$ ) and $w_{i}{ }^{\mathrm{PM}}$ units to work (where $w_{i}^{\mathrm{PM}}>w_{i}^{\mathrm{D}}$ ), and not to raid, as long as the other player has never raided and has also allocated $w_{-i}{ }^{\mathrm{PM}}$ to work and $m_{-i}{ }^{\mathrm{PM}}$ to military preparedness. Furthermore, the strategy calls for raiding and then reverting to playing the all-defect strategy forever if the other player has ever allocated units $m_{-i} \quad m_{-i}^{\mathrm{PM}}$ to military ability or more than $w_{-i}{ }^{\mathrm{PM}}$ units to productive labor, player I will raid and revert to playing the all-defect strategy forever.

$$
\begin{aligned}
& \text { Define } m_{i}^{\mathrm{PM}} \text { and } w_{i}^{\mathrm{PM}} \text { to be:: } \\
& \left(w_{i}^{P M}, m_{i}^{P M}, l_{i}^{P M}\right) \in \underset{w_{i}, m_{i}, l_{i} \in[0, R]}{\arg \max } U\left(F\left(w_{i}\right)+F\left(w_{-i}^{P M}\right) M\left(m_{i}, m_{-i}^{P M}\right)-F\left(w_{i}\right) M\left(m_{-i}^{P M}, m_{i}\right), l_{i}\right)
\end{aligned}
$$

A PM strategy profile, $\sigma^{\mathrm{PM}}$, is a symmetric (most efficient PM) equilibrium iff for $i=1$, 2:

$$
\frac{\pi_{i}^{P M}}{\left(1-\delta_{i}\right)} \geq \pi_{i}^{D, P M}+\frac{\delta_{i} \pi_{i}^{D}}{\left(1-\delta_{i}\right)}
$$

where (like in the NM equilibrium) ${ }_{i}{ }^{\mathrm{D}, \mathrm{PM}}$ is the highest payoff attainable from one period deviation when the other player continues to play her PM strategy. That is,

$$
\pi_{i}^{D, P M}(\bullet)=\max _{w_{i}^{D, P M}, m_{i}^{D, P M}, l_{i}^{D, P M}} U\left(F\left(w_{i}^{D, P M}\right)+F\left(w_{-i}^{P M}\right) M\left(m_{i}^{D, P M}, m_{-i}^{P M}\right), l_{i}^{D, P M}\right)
$$

Welfare implications of PM equilibrium:

A necessary and sufficient condition for the existence of a PM allocation that pareto dominates a NM equilibrium allocation is at $w_{i}^{\mathrm{NM}}, l_{i}^{\mathrm{NM}}, \quad \mathrm{U}_{i}(\bullet) / m_{i}+\mathrm{U}_{i}(\bullet) / w_{i}+\mathrm{U}_{i}$ $(\bullet) / \quad l_{i}>0$. A necessary and sufficient condition for this PM allocation to be sustained in a PM equilibrium is that,

$$
\frac{\pi_{i}^{P M}-\pi_{i}^{N M}}{\left(1-\delta_{i}\right)} \geq \pi_{i}^{D, P M}-\pi_{i}^{D, N M} .
$$

Thus, a shift to a PM equilibrium from a NM equilibrium may improve social welfare, despite the wasteful military spending. 


\section{PART II: Societies with States}

\section{Cooperative Governance Equilibrium}

In a cooperative governance equilibrium, private agents pay taxes and refrain from raiding, as long as $\mathrm{G}$ does not expropriate their property; should they raid or fail to pay taxes $\mathrm{G}$ will punish them by reverting to predatory behavior.

In such an equilibrium, G's strategy is,

$\sigma_{\mathrm{G}}=\left\{\left(\mathrm{G}\right.\right.$ refrains from expropriating private agents' property $\left(p_{i}, p_{-i}\right)=(0,0)$, if private agents have paid taxes and not raided $t_{i}=1$ and $r_{i}=0, \forall i$; G reverts to predatory behavior $\left(p_{i}, p_{-i}\right)=(0,1)$ or $\left(p_{i}, p_{-i}\right)=(1,0)$, if a private agent raids or fails to pay taxes $r_{i}=$ 1 or $\left.\left.t_{i}=0, \forall i\right)\right\}$.

The private agents' follow the strategy,

$\sigma_{i}=\{($ as long as $\mathrm{G}$ has not preyed or failed to punish a transgressing private agent, player $i$ does not raid $r_{i}=0$, pays taxes $t_{i}=1$, and chooses levels of $w_{i}, m_{i}, l_{i}$ such that, given G's strategy, player $-i$ also allocates the equilibrium level of resources to $w_{-i}, m_{-i}, l_{-i}$ and does not raid $r_{-i}=0$; player $i$ reverts to raiding and allocating resources accordingly, if $\mathrm{G}$ has neglected to punish a private agent who has transgressed or if $\mathrm{G}$ has expropriated property when private agents have not transgressed) $\}$, for $i=1,2$.

Denote by ${ }_{i}{ }^{\mathrm{CG}}$ the per period payoff of private agent $i$ on the path of play,

$$
\begin{gathered}
\partial_{i}{ }^{\mathrm{CG}}\left(w_{i}{ }^{\mathrm{CG}}, m_{i}{ }^{\mathrm{CG}}, l_{i}^{\mathrm{CG}}, r_{i}=0, t_{i}=1, p_{i}=0, w_{-i}{ }^{\mathrm{CG}}, m_{-{ }_{-}}{ }^{\mathrm{CG}}, l_{-{ }_{i}}{ }^{\mathrm{CG}}, r_{-}=0, t_{-}{ }_{i}=1, p_{-}{ }_{i}=0\right)= \\
\mathrm{U}\left(\mathrm{F}\left(w_{i}{ }^{\mathrm{CG}}\right)\left(1-t_{i} \tau\right), l_{i}{ }^{\mathrm{CG}}\right) .
\end{gathered}
$$

$(A-13)$

Define $\widehat{\partial}_{i}^{\mathrm{D}, \mathrm{CG}}$ as the highest one period payoff obtainable for player $i$ by deviating from the CG strategy when player $-i$ follows it. That is,

$$
{\partial_{i}}^{\mathrm{D}, \mathrm{CG}}(\bullet)=\mathrm{U}\left(\left[\mathrm{F}\left(w_{i}{ }^{\mathrm{D}, \mathrm{CG}}\right)+\mathrm{F}\left(w_{-i}{ }^{\mathrm{CG}}\right) \mathrm{M}\left(m_{i}^{\mathrm{D}, \mathrm{CG}}, m_{-}{ }_{i}^{\mathrm{CG}}\right)\right]\left(1-q_{i}\right), l_{i}^{\mathrm{CG}}\right) \text {. }
$$

Note that since private agent $i$ chooses whether or not to pay taxes, the most profitable deviation entails not paying her taxes. Finally, remember that $\partial_{i}{ }^{\mathrm{WL}}$ is player $i$ 's payoff in the warlord equilibrium (described below).

The cooperative governance (CG) strategy combination is a SPNE if ${ }^{43}$ for $i=1,2$ :

$$
\tau^{C G}=\frac{\left[q_{i} F\left(w_{i}^{C G}\right)-C_{G}(\bullet)\right]\left(1-\delta_{G}\right)}{F\left(w_{i}^{C G}\right)\left[2 \delta_{G}+q_{i}\left(1-\delta_{G}\right)\right]}+\frac{\boldsymbol{\delta}_{G} \pi_{G}^{W L}}{F\left(w_{i}^{C G}\right)\left[2 \delta_{G}+q_{i}\left(1-\delta_{G}\right)\right]}
$$

$$
q_{i} F\left(w_{i}^{C G}\right) \geq C_{G}(\bullet)
$$

\footnotetext{
${ }^{43}$ Examining the sufficient condition for this strategy to be an equilibrium complicates the presentation without adding insights.
} 
(iii)

$$
\begin{aligned}
& w_{i}^{C G}, m_{i}^{C G}, l_{i}^{C G} \in \underset{w_{i}, m_{i}, l_{i} \in[0, T]}{\arg \max } U\left(F\left(w_{i}\right)\left(1-\tau^{C G}\right), l_{i}^{C G}\right) \\
& \text { subject to } w_{i}^{C G}+m_{i}^{C G}+l_{i}^{C G}=T, \text { and } \frac{\pi_{-i}^{C G}}{\left(1-\boldsymbol{\delta}_{-i}\right)} \geq \pi_{-i}^{D, C G}+\frac{\boldsymbol{\delta}_{-i} \pi_{-i}^{W L}}{\left(1-\boldsymbol{\delta}_{-i}\right)} \\
& \frac{\pi_{i}^{C G}}{\left(1-\boldsymbol{\delta}_{i}\right)} \geq \pi_{i}^{D, C G}+\frac{\boldsymbol{\delta}_{i} \pi_{i}^{W L}}{\left(1-\boldsymbol{\delta}_{i}\right)}
\end{aligned}
$$

where $i^{\mathrm{D}, \mathrm{CG}}$ is the payoff an economic agent can obtain by deviating from the CG equilibrium (it is defined in a manner similar to A-11 above).

The CG strategy profile constitutes a SPNE if no player can gain from a single action deviation after any history, which will be the case if the above conditions are met.

Equation (A-15) ensures the optimality of G's action on the path of play; it specifies a tax rate, $\tau^{\mathrm{CG}}$, sufficiently high to deter $\mathrm{G}$ from attacking private agents who are expected to pay it. To keep $\mathrm{G}$ from defecting the following condition must hold: $\frac{\pi_{G}^{C G}}{\left(1-\delta_{G}\right)} \geq \pi_{G}^{D, C G}+\frac{\delta_{G} \pi_{G}^{W L}}{\left(1-\delta_{G}\right)}(A-19)$, where ${ }_{\mathrm{G}}{ }^{\mathrm{D}, \mathrm{CG}}$ is G's highest per period payoff from deviating from the CG strategy while the private agents are still playing the CG strategy (i.e., $\mathrm{G}$ engages in predatory behavior against one even though both have already paid taxes to $\mathrm{G}$ for the period). By definition,

$$
{\partial_{\mathrm{G}}}^{\mathrm{D}, \mathrm{CG}}=q_{i}\left[\mathrm{~F}\left(w_{i}{ }^{\mathrm{CG}}\right)-\tau^{\mathrm{CG}} \mathrm{F}\left(w_{i}{ }^{\mathrm{CG}}\right)\right]-\mathrm{C}_{\mathrm{G}}(\bullet)+2 \tau^{\mathrm{CG}} \mathrm{F}\left(w_{i}{ }^{\mathrm{CG}}\right) \text {, and } \partial_{\mathrm{G}}{ }^{\mathrm{CG}}=2 \tau^{\mathrm{CG}} \mathrm{F}\left(w_{i}{ }^{\mathrm{CG}}\right)
$$

$\tau^{\mathrm{CG}}$ is derived from equation (A-19) when the RHS equals the LHS. $\tau^{\mathrm{CG}}$ is the lowest tax rate that will deter $\mathrm{G}$ from defecting from the $\mathrm{CG}$ equilibrium and expropriating private agents' property. Any tax above this amount would not be credible. Private agents would not find it optimal to pay a higher tax. Implicit in this argument is the assumption that private agents determine how much tax to pay. It is easy to incorporate this implicit assumption explicitly into the model; for simplicity sake, we do not do so here.

The next condition guarantees the optimality of G's action in response to an agent's deviation; $G$ finds it profitable to punish if any agent raids or does not pay at least $\tau^{\mathrm{CG}} \mathrm{F}\left(\mathrm{w}_{i}{ }^{\mathrm{CG}}\right)$ when equation $(A-16)$ holds. Finally, the last condition binds the private agents to stay on-the-equilibrium path by ruling out any profitable deviations on the path of play. Equations $(A-17)$ and $(A-18)$ require that a private agent choose the optimal allocation of work and military ability that still deters the other agent from raiding or acquiring more than the equilibrium level of military ability. Equation (A-18) requires that the economic agents prefer to be on the $\mathrm{CG}$ equilibrium path rather than to deviate from it, thus reverting to the WL equilibrium. 


\section{Warlord Equilibrium}

Consider the following warlord equilibrium (WL) strategy profile, $\sigma_{1}{ }^{W L}$, for each player: Each player raids the other after investing $m_{i}{ }^{\mathrm{WL}}$ in military ability; $w_{i}{ }^{\mathrm{WL}}$ in work; and $\mathrm{T}-m_{i}{ }^{\mathrm{WL}}-w_{i}{ }^{\mathrm{WL}}$ in leisure, where $0<m_{i}{ }^{\mathrm{WL}}, w_{i}{ }^{\mathrm{WL}}$; the per period payoff for each player for this equilibrium strategy combination is ${\partial_{i}}^{\mathrm{WL}}$. In G's WL strategy profile, $\sigma_{1}{ }^{\mathrm{WL}}$, $\mathrm{G}$ randomly raids one player each period for a payoff of $\partial_{G}{ }^{\mathrm{WL}}$.

In a one-period game, the allocations can be achieved as a sub-game perfect Nash equilibrium outcome iff for $i=1,2$ :

$$
w_{i}^{W L}, m_{i}^{W L}, l_{i}^{W L} \in \underset{w_{i}, m_{i}, l_{i} \in[0, T]}{\arg \max } \pi^{W L}{ }_{i}\left(w_{i}, m_{i}, l_{i}=T_{i}-w_{i}-m_{i}, r_{i}=1, \tau_{i}=0, w_{-i}^{W L}, m_{-i}^{W L}, l_{-i}^{W L}=T-w_{-i}^{W L}-m_{-i}^{W L}, r_{-i}:\right.
$$

where

$$
\pi_{i}^{W L}(\bullet)=\max _{w_{i}^{W L}, m_{i}^{W L}, l_{i}^{W L}} U\left(\left(1-p_{i} q_{i}\right)\left[F\left(w_{i}^{W L}\right)+F\left(w_{-i}^{W L}\right) M\left(m_{i}^{W L}, m_{-i}^{W L}\right)-F\left(w_{i}^{W L}\right) M\left(m_{-i}^{W L}, m_{i}^{W L}\right)\right], l_{i}^{W L}\right)
$$

subject to $w_{i}+m_{i}+l_{i}=\mathrm{T}$. The payoff for $\mathrm{G}$, the specialist in violence, is $\pi_{G}^{W L}(\bullet)=q_{i} F\left(w_{i}^{W L}\right)-C_{G}(A-53)$.

\section{Comparative statics for the CG equilibrium:}

Discount factor. G's time horizon as represented by the discount factor parameter, $\delta_{\mathrm{G}}$, affects the most efficient cooperative governance equilibrium. From equation $(A-19)$, we know that the most efficient CG equilibrium is defined by $\pi_{G}^{C G}=\pi_{G}^{D, C G}\left(1-\delta_{G}\right)+\delta_{G} \pi_{G}^{W L}$. Taking the derivative with respect to $\delta_{G}$ yields $\frac{\partial \pi_{G}^{C G}}{\partial \delta_{G}}=\pi_{G}^{W L}-\pi_{G}^{D, C G}+\left(1-\delta_{G}\right) \frac{d \pi_{G}^{W L}}{d \delta_{G}}$. Since, by construction $\pi_{G}^{W L}<\pi_{G}^{D, C G}$ and by the envelope theorem $\frac{d \pi_{G}^{W L}}{d \boldsymbol{\delta}_{G}}=0, \frac{\partial \pi_{G}^{C G}}{\partial \delta_{G}}<0$ (A-54). This implies that as G's discount factor increases ( $\mathrm{G}$ becomes more patient), the cooperative governance equilibrium can be sustained for lower levels of $\partial_{G}{ }^{C G}$. Similarly, we can show that $\frac{\partial \pi_{G}^{W L}}{\partial \delta_{G}}>0 \quad(A-25)$. Thus, as $\mathrm{G}$ values the future more, even larger temptations to defect from the cooperative governance equilibrium can be sustained in equilibrium.

From equation $(A-15)$, we can see that as $\delta_{\mathrm{G}} \rightarrow 1, \tau^{C G} \rightarrow \frac{\pi_{G}^{W L}}{2 F\left(w_{i}^{C G}\right)}$. As G becomes more patient, the equilibrium tax rate declines. 
Continuation value. Equation (A-15) implies that as $\partial_{\mathrm{G}}{ }^{\mathrm{CH}}$ increases, the lowest tax rate, $\tau^{\mathrm{CG}}$, that deters $\mathrm{G}$ from attacking tax-paying private agents, will also rise $\left(\tau^{\mathrm{CG}} / \partial_{\mathrm{G}}{ }^{\mathrm{CH}}>\right.$ $0)$. In other words, if equation $(A-15)$ holds in equality and $\partial_{\mathrm{G}}{ }^{\mathrm{CH}}$ increases and the tax rate does not, $\mathrm{G}$ will no longer have an incentive to adhere to the cooperative governance equilibrium.

Another way to think about this is that, when ${{ }_{\mathrm{G}}}_{\mathrm{G}}{ }^{\mathrm{CH}}$ increases, in order maintain the conditions in (A-19), $\partial_{\mathrm{G}}{ }^{\mathrm{CG}}$ will also have to increase (in other words, the tax rate must increase to compensate). As G's options off-the-equilibrium path improve (i.e., $\partial_{\mathrm{G}}{ }^{\mathrm{CH}}$ increases), it becomes increasingly unlikely that (A-15 and $A-19)$ will hold and therefore that $\mathrm{G}$ will refrain from predatory behavior. The continuation value, $\partial_{\mathrm{G}}{ }^{\mathrm{CH}}$, is a critical parameter in determining the feasibility of the CG equilibrium: ceteris paribus, it determines whether there exists a tax rate high enough to bribe $G$ to refrain from predatory behavior, but low enough to make G's services worth paying for.

$\underline{\text { Taxes. }}$ Comparative statics analysis reveals how $\tau^{\mathrm{CG}}$ varies with $\mathrm{F}(\bullet)$, income: from equation (A-15), we can show that $\tau^{\mathrm{CG}} / \mathrm{F}(\bullet)>0$ for $\delta_{\mathrm{G}}<1 / 3$ and $q>\frac{2 \delta_{G}}{1-\delta_{G}}$, otherwise if $\delta_{\mathrm{G}}>1 / 3$ or $q<\frac{2 \delta_{G}}{1-\delta_{G}}, \quad \tau^{\mathrm{CG}} / \mathrm{F}(\bullet)<0 .(A-26)$

Similarly, we can also compute how $\tau^{\mathrm{CG}}$ varies with $q$, G's ability to extract income from private agents it chooses to attack - for punishment or predation: $\tau^{\mathrm{CG}} / q$ $>0$. $(A-27)$

\section{Welfare implications of the CG equilibrium:}

Now, we want to see if governments can enhance social welfare. Private agent $i$ 's payoff from defection $\partial_{i}{ }^{\mathrm{D}, \mathrm{CG}}$ varies inversely with the government's ability to confiscate property, as indexed by $q$. Given that $\partial_{i}{ }^{\mathrm{D}, \mathrm{GP}} / \quad q_{i}<0$, as $q \rightarrow 1$, agent $i$ 's income $\mathrm{I}_{i}{ }^{, \mathrm{D}, \mathrm{CG}}(\bullet) \rightarrow 0$. As the government's ability to appropriate a private agent's wealth increases, i.e. as $q \rightarrow 1$, the distortion introduced by investments in military capabilities goes to zero. However, governments differ in the losses they inflict from taxation. The magnitude of such losses, we have seen, depend on what the government could expect to gain, were it to remain on, or to stray off, the equilibrium path. The magnitude of its reservation value, $\partial_{\mathrm{G}}{ }^{\mathrm{WL}}$, thus provides the foundations for the welfare analysis. In fact if $\partial_{\mathrm{G}}{ }^{\mathrm{WL}}=0$ as both $q$ and $\delta_{\mathrm{G}} \rightarrow 1$, the CG equilibrium can Pareto dominate the most efficient NM equilibrium and approach the first best outcome. In other words, the most efficient CG equilibrium is the one in which ${\partial_{i}}^{\mathrm{WL}} \quad{\partial_{i} \mathrm{D}}$ and $\lim {\partial_{i}}^{\mathrm{CG}}>{\partial_{i}}^{\mathrm{NM}}$ as $\delta_{\mathrm{G}} \rightarrow 1$, and $\lim {\partial_{i}}^{\mathrm{CG}}$ $\rightarrow \mathrm{d}_{i}^{\mathrm{FB}}$ as $q \rightarrow 1$ and $\delta_{\mathrm{G}} \rightarrow 1$.

Let's start by supposing that ${\partial_{\mathrm{G}}}^{\mathrm{WL}}=0$ and a CG equilibrium exists. Recall that ${\partial_{i}}^{C G}$ is the per period payoff to private agent $i$ in a CG equilibrium and that $\partial_{i}{ }^{\mathrm{NM}}$ is private agent $i$ 's per period payoff in the most efficient NM equilibrium (that is, the most efficient no military investment equilibrium in the repeated game without $G$ ). 
In the most efficient CG equilibrium, ${ }_{i}{ }^{\mathrm{WL}}$ must be the lowest possible to minimize distortion due to taxation. Hence, $\partial_{i}{ }^{\mathrm{WL}} \quad \partial_{i}{ }^{\mathrm{D}}$. To see why this is the case note that if $\partial_{\mathrm{G}}{ }^{\mathrm{WL}}=0$ then $(a)$ the agents do not pay tax and either $(b) \mathrm{G}$ does not prey or $(c) \mathrm{G}$ preys and the expected net income from preying is zero. If $(a)$ and $(b)$ hold then the

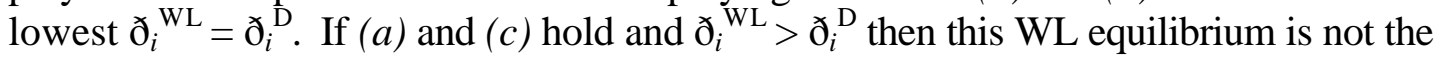
most efficient.

The condition that determines the highest payoffs possible in a NM equilibrium in the absence of $\mathrm{G}$ is equation $(A-7): \frac{\pi_{i}^{N M}}{\left(1-\delta_{i}\right)} \geq \pi_{i}^{D, N M}+\frac{\delta_{i} \pi_{i}^{D}}{\left(1-\delta_{i}\right)}$. The equivalent condition in the game with a government is: $\frac{\pi_{i}^{C G}}{\left(1-\delta_{i}\right)} \geq \pi_{i}^{D, C G}+\frac{\delta_{i} \pi_{i}^{W L}}{\left(1-\delta_{i}\right)}$. Recall that ${\partial_{i}}^{\mathrm{NM}}$ reflects the distortion due to the need to deter violence by shifting effort from work to leisure; ${ }_{i}{ }^{\mathrm{CG}}$ reflects this distortion to a lesser degree (since G's punishment for raiding is added) but adds inefficiency from the reallocation of resources to leisure due to taxation. Suppose for the moment that the latter distortion is zero (as $\delta_{\mathrm{G}} \rightarrow 1$, for example). Comparing the two conditions indicates that at the NM equilibrium allocation of work effort, $w_{i}{ }^{\mathrm{NM}}$, the latter condition does not bind while the former does. That is, $\frac{\pi_{i}^{N M}}{\left(1-\delta_{i}\right)}>\pi_{i}^{D, C G}+\frac{\delta_{i} \pi_{i}^{W L}}{\left(1-\delta_{i}\right)}$.

The CG equilibrium Pareto dominates the most efficient $\mathrm{NM}$ equilibrium if the distortion due to taxation goes to zero. Equation $(A-15)$ determines the lowest tax rate for which $\mathrm{G}$ is deterred from predation; this tax rate converges to zero as G's time discount factor approaches one and ${\partial_{\mathrm{G}}}^{\mathrm{WL}}=0$ (see discussion above under discount factor),

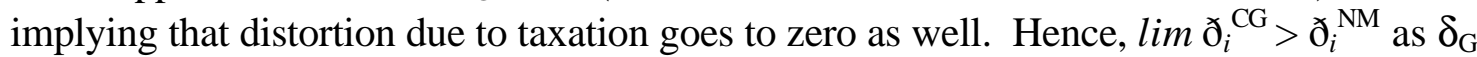
$\rightarrow 1$.

Condition (A-17) implies that $\lim w_{i}^{\mathrm{CG}} \rightarrow w_{i}^{\mathrm{FB}}$ as $q_{i} \rightarrow 1$ and $\delta_{\mathrm{G}} \rightarrow 1$. Hence, and $\lim {\partial_{i}}^{\mathrm{CG}} \rightarrow{\mathrm{d}_{i}}^{\mathrm{FB}}$ as $q_{i} \rightarrow 1$ and $\delta_{\mathrm{G}} \rightarrow 1$.

Thus, when $\partial_{\mathrm{G}}{ }^{\mathrm{WL}} \rightarrow 0$, coercion can promote, rather than stifle, productive activity, if the "specialist in violence" is sufficiently patient and sufficiently strong. Indeed, no matter how impatient the private agents (that is, no matter how low $\delta_{i}$ ), the CG outcome Pareto dominates the outcome achieved by threats of citizen soldiers acting alone. In the limit, governments can secure the first best outcome as an equilibrium. 


\section{References}

Addison, Tony, Philippe Le Billon, and S. Mansoob Murshed. 2000. Conflict in Africa: The Cost of Peaceful Behavior. Working paper. WIDER. Helsinki, Findland.

Ake, Claude. 1990. The Case for Democracy. Paper read at African Governance in the 1990s, at Atlanta.

Andersen, Lisa. 1986. The State and Social Transformation. Princeton: Princeton University Press.

Axelrod, Robert. 1984. The Evolution of Cooperation. New York: Basic Books.

Azam, Jean_Paul. 1994. How to Pay for Peace? A Theoretical Framework with Reference to African Countries. Public Choice 83:173-184.

Barnett, Don, and Karari Njama. 1966. Mau Mau from Within. New York: Monthly Review Press.

Bates, Robert H. 1983. The Preservation of Order in Stateless Societies. In Essays on the Political Economy of Rural Africa, R. H. Bates. Berkeley and Los Angeles: University of California Press.

Bates, Robert H., and Paul Collier. 1991. The Case of Zambia. In Political and Economic Interactions in Economic Policy Reform, edited by R. H. Bates and A. O. Krueger. Oxford: Blackwell.

Beblawi, Hazen, and Luciani Giacomi, eds. 1987. The Rentier State. London: Croom Helm.

Block, Steven, Karen Ferree, and Smita Singh. 2000. The Curses and Blessings of Elections: Electoral Competitiveness and Political Business Cycles in D eveloping Countries. Manuscript. Cambridge MA.

Chaudry, Kiren Aziz. 1997. The Price of Wealth. Ithaca: Cornell University Press.

Clough, Marshall S., and Kernell A. Jackson. 1975. Mau Mau Syllabus: Parts I and II. Stanford CA: Stanford University.

Cohat, Yves. 1992. The Vikings. London: Thames and Hudson.

Cohen, Youssef, Brian Brown, and A. K. F. Organski. 1981. The Paradoxical Nature of State Making: The Violent Creation of Political Order. American Political Science Review:901-910.

Collier, Paul and Anke Hoeffler. 1998. On Economic Causes of Civil War. Oxford Economic Papers 50 (4):563-73.

Colson, Elizabeth. 1974. Tradition and Contract. Chicago: Aldine Publishing Company.

Cowen, Michael P. 1978. Capital and Household Production: The Case of Wattle i Kenya's Central Province, 1903-1964. Ph.D. Dissertation, Anthropology, Cambridge University, Cambridge.

Crouch, David. 1990. William Marshall. New York: Longman. 
Dike, K. Onwuka. 1956. Trade and Politics in the Niger Delta, 1830-1885. Oxford: The Clarendon Press.

Duby, Georges. 1987. France in the Middle Ages, 987-1460. Translated by Juliet Vale. Oxford: Blackwell.

Edgerton, R. E. (1989). Mau Mau: An African Crucible. New York, The Free Press.

Elbadawi, Ibrahim. 1999. Civil Wars and Poverty. Washington DC: Development Economics Research Group, the World Bank.

Ellis, Stephen. 1999. The Making of Anarchy. New York: New York University Press.

Evans, Peter. 1995. Embedded Autonomy. Princeton: Princeton University Press.

Fearon, James D. 1996. Bargaining Over Objects that Influence Future Bargaining Power. In Paper Presented to the 1997 Annual Meeting of the American Political Science Association. Washington DC.

Feudenberg, Drew, and Eric Maskin. 1986. The Folk Theorem in Repeated Games with Discounting and Incomplete Information. Econometrica 54:533-54.

Findlay, Ronald. 1991. The New Political Economy: Its Explanatory Power for LDC's. In Politics and Policy Making in Developing Countries, ed. Geralld Meier. San Francisco: International center for Economic Growth. Garfinkel, Michelle and S. Skaperdas. 2000. Contract or War? On the consequences of a broader view of self-interest in economics. Working paper. Economics Dep. University of California, Irvine.

Greif, Avner. 1998. Self-enforcing Political Systems and Economic Growth: Late Medieval Genoa. In Analytic Narratives, edited by R. H. Bates, A. Greif, J.-L. Rosenthal, M. Levi and B. Weingast. Princeton: Princeton University Press.

Grindle, Marilee. 1991. The New Political Economy. In Politics and Policy Making in Developing Countries, ed. Geralld Meier. San Francisco: International center for Economic Growth.

Grossman, Herschel I. 1991. A General Equilibrium Model of Insurrections. American Economic Review 81 (4):912-921.

Grossman, Herschel. 1997. 'Making us a King:' Anarchy, Predation, and the State. In NBER Working Paper 6289. Cambridge MA.

Grossman, Herschel I, and Minseong Kim. 1995. Swords or Ploughshares? A Theory of the Security Claims to Property. Journal of Political Economy 103 (1275-1288).

Hicks, Michael. 1995. Bastard Feudalism. London and New York: Longman.

Hirshleifer, Jack. 1995. Theorizing About Conflict.In Handbook of Defense Economics, ed. K. H. a. T. Sandler. New York: Elsevier.

Hobbes, Thomas. 1947. The Leviathan. Translated by Dent, J. M. New York: E. P. Dutton.

Hogue, Arthur R. 1966. The Origins of Common Law. Bloomington ID: Indiana University Press. 
Hudson, John. 1996. The Formation of the English Common Law. New York and London: Longman.

Huntington, Samuel P. 1991. The Third Wave. Norman, OK: Oklahoma University Press.

Jones, Gwilym Iwan. 1963. The Trading States of the Oil Rivers. London: Oxford University press for the International African Institute.

Kenyatta, Jomo. 1953. Facing Mount Kenya. London: Secker and Warburg.

Keohane, Robert. 1984. After Hegemony. Princeton NJ: Princeton University Presx.

Kershaw, Greet. 1997. Mau Mau from Below. Athens, Ohio: Ohio University Press.

Kitching, Gavin. 1980. Class and Economic Change in Kenya. London and New Haven: Yale University Press.

Klebnikov, Paul. 2000. Godfather of the Kremlin: Boris Berezovsky and the Looting of Russia. New York: Harcourt.

Konrad, Kai, and Stergios Skaperdas. 1996. The Market for Protection and the Origin of the State. In Paper Prepared for Conference on Political Violence at Princeton University. Princeton NJ.

Lal, Deepak. 1984. The Poverty of Development Economics. London: The Institute of Economic Affairs.

Lambert, H. E. 1956. Kikuyu Social and Political Institutions. London: Oxford University Press.

Leakey, Louis S. B. 1977. The Southern Kikuyu Before 1903. 3 vols. London: Academic Press.

Levi, M. (1988). Of Rule and Revenue. Berkeley and Los Angeles, University of California Press.

MacCaffrey, Wallace T. 1961. Place and Patronage in Elizabethan Politics. In Elizabethan Government and Society, edited by S. T. Bidoff, J. Hurstfield and C. H. Williams. London: The Athlone Press.

Mahdavy, Hussein. 1970. The Patterns and Problems of Economic Development in Rentier States: The Case of Iran. In Studies in Economic History of the Middle East, edited by M. A. Cook. New York: Oxford University Press.

McFarlane, K. B. (1973). The Nobility of Later Medieval Europe. Oxford, Clarendon Press.

McFarlane, K. B. (1981). England in the 15th Century. London, Hambledon Press.

McMillan, Margaret S., and William Masters. 2000. Africa's Growth Trap: A PoliticalEconomy Model of Taxation, R\&D and Investment. In Working Paper.

Cambridge MA: Center for International Development Harvard University.

Middleton, J. 1953. The Central Tribes of the North-Eastern Bantu. London: International African Institute.

Migdal, Joel. 1975. Peasants, Politics, and Revolution. Princeton NJ: Princeton 
University.

Moore, Barrington. 1966. Social Origins of Dictatorship and Democracy. Boston: Beacon Press.

Moselle, Boaz, and Ben Polak. 1999a. Anarchy, Organized Crime, and Extortion: A Cynical Theory of the State. Paper Prepared for the Conference on Political Violence, Princeton University. Princeton NJ.

Moselle, Boaz, and Ben Polak. 1999b. A Model of the Predatory State. In Paper Prepared for Conference on the Breakdown of States, Princeton University. Princeton NJ.

Munz, Peter. 1969. Frederick Barbarossa. Edited by Ithaca, Cornel University Press.

Muthoo, Abhinay. 2000. On the Foundations of Property Rights, Part I: A Model of the State-of-Nature with Two Players. Typescript, Department of Economics. Essex, UK.

Ndulu, Benno, and Stephen A. O'Connell. 1999. Governance and Growth in Sub-Saharan Africa. Journal of Economic Perspectives 13 (3):41-66.

Njonjo, Apollo. 1997. The Africanization of the 'White Highlands', PhD Dissertation, Department of Politics, Princeton University, Princeton.

North, Douglass C. 1981. Structure and Change in Economic History. New York: Norton.

North, Douglass C. 1990. Institutions, Institutional Change, and Economic Performance. New York: Cambridge University Press.

Northrup, David. 1978. Trade Without Rulers. Oxford: Clarendon Press.

Olson, Mancur. 1993. Dictatorship, Democracy, and Development. American Political Science Review 87 3: 567-75.

Ormrod, W. M. 1993. The Reign of Edward III. New Haven and London: Yale University Press.

Ottenberg, Simon. 1958. Ibo Oracles and Intergroup Relations. Southwestern Journal of Anthropology 14 (3):295-317.

Parker, Geoffrey. 1991. The Military Revolution: Military Innovation and the Rise of the West, 1500-1800. New York: Cambridge University Press.

Power, Eileen. 1941. The Wool Trade in English Medieval History. Oxford: Oxford University Press.

Prestwich, Michael. 1980. Edward I. New Haven and London: Yale University Press.

Przeworski, Adam. 1991. Democracy and the Market. Cambridge: Cambridge University Press.

Reno, W. (1998). Warlord Politics and African States. Boulder, CO, Lynne Rienner Publishers.

Rosberg, Carl G., and John Nottingham. 1966. The Myth of Mau Mau. Stanford CA: 
Praeger of New York for the Hoover Institution of War, Revolution and Peace.

Ross, Michael L. 2000. Does resource Wealth Cause Authoritarian Rule? In Paper Presented to the Annual Meeting of he American Political Science Association, Washington D.C. August 31-September 3.

Sachs, Jeffrey D., and Andrew M. Warner. 1995. Natural Resource Abundance and Economic Growth. In Development Discussion Paper No 5179, Harvard Institute for International Development. Cambridge MA.

Sachs, Jeffrey D., and Andrew M. Warner. 1999. The Big Push, Natural Resource Booms, and Growth. Journal of Development Economics 59 (1):43-76.

Scott, James C. 1976. The Moral Economy of the Peasant. New Haven and London: Yale University Press.

Shleifer, Andrei, and Daniel Triesman. 2000. Without a Map: Political Tactics and Economic reform in Russia. Cambridge: The MIT Press.

Sisk, T. D. and A. Reynolds, Eds. (1998). Elections and Conflict Management in Africa. Washington DC, United States Institute of Peace.

Skaperdas, Stergios. 1992. Cooperation, Conflict, and Power in the Absence of Property Rights. American Economic Review 82 (4):720-738.

Skaperdas, Stergios. 1996. “Contest Success Functions.” Economic Theory, 7, pp. 283290.

Skarpedas, Stergios. 1996. Gangs and the State of Nature. In The New Palgrave Dictionary of Economics and the Law, edited by P. Newman. London: Palgrave.

Skarpedas, Stergios, and Constantinos Syropoulos. 1995. Gangs as Primitive States. In The Economics of Organized Crime, edited by G. Fiorentini and S. Peltzman. New York: Cambridge University Press.

Skaperdas, Stergios, and Constantinos Syropoulos. 1996. Insecure Property Rights and the Stability of Exchange. In Technical Report. Institute for Mathematical Behavioral Science: Pennsylvania State University.

Skocpol, Theda. 1979. States and Social Revolutions. Cambridge: Cambridge University Press.

Southall, Aidan W. 1956. Alur Society. Cambridge: W. Heffer and Sons.

Tabacco, Giovanni. 1989. The Struggle for Power in Medieval Italy. Vol. ` Cambridge: Cambridge University Press.

Taylor, Michael. 1987. The Possibility of Cooperation. New York: Cambridge University Press.

Treisman, Daniel. 1999. After the Deluge: Regional Crisis and Political Consolidation in Russia. Ann Arbor: University of Michigan Press.

Usher, Dan. 1989. The Dynastic Cycle and the Stationary State. American Economic Review 79 (5):1031-1044. 
Waley, Daniel. 1988. The Italian City Republics. Reprint ed. New York: McGraw Hill.

Weber, Max. 1958. Politics as a Vocation. In From Max Weber, edited by H. H. Gerth and C. W. Mills. New York: Oxford University Press.

Wolf, Eric R. 1969. Peasant Wars of the Twentieth Century. New York: Harper and Row.

World Bank. 1991. Governance and Development. Washington DC: The World Bank. 